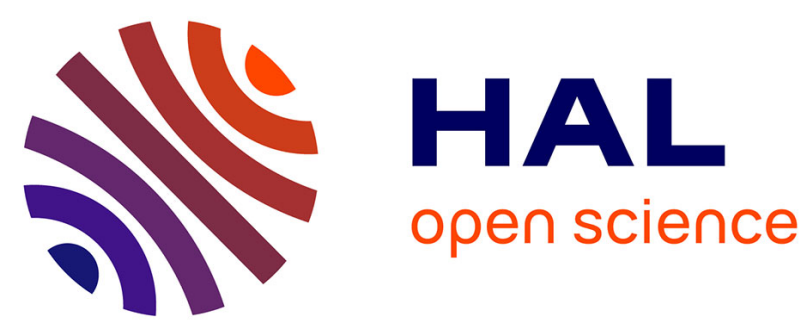

\title{
Effects of a combretastatin A4 analogous chalcone and its Pt-complex on cancer cells: a comparative study of uptake, cell cycle and damage to cellular compartments
} Miroslava Zoldakova, Zsuzsanna Kornyei, Andreas Brown, Bernhard Biersack, Emília Madarász, Rainer Schobert

\section{To cite this version:}

Miroslava Zoldakova, Zsuzsanna Kornyei, Andreas Brown, Bernhard Biersack, Emília Madarász, et al.. Effects of a combretastatin A4 analogous chalcone and its Pt-complex on cancer cells: a comparative study of uptake, cell cycle and damage to cellular compartments. Biochemical Pharmacology, 2010, 80 (10), pp.1487. 10.1016/j.bcp.2010.07.046 . hal-00626229

\section{HAL Id: hal-00626229 \\ https://hal.science/hal-00626229}

Submitted on 24 Sep 2011

HAL is a multi-disciplinary open access archive for the deposit and dissemination of scientific research documents, whether they are published or not. The documents may come from teaching and research institutions in France or abroad, or from public or private research centers.
L'archive ouverte pluridisciplinaire HAL, est destinée au dépôt et à la diffusion de documents scientifiques de niveau recherche, publiés ou non, émanant des établissements d'enseignement et de recherche français ou étrangers, des laboratoires publics ou privés. 


\section{Accepted Manuscript}

Title: Effects of a combretastatin A4 analogous chalcone and its Pt-complex on cancer cells: a comparative study of uptake, cell cycle and damage to cellular compartments

Authors: Miroslava Zoldakova, Zsuzsanna Kornyei, Andreas Brown, Bernhard Biersack, Emília Madarász, Rainer Schobert

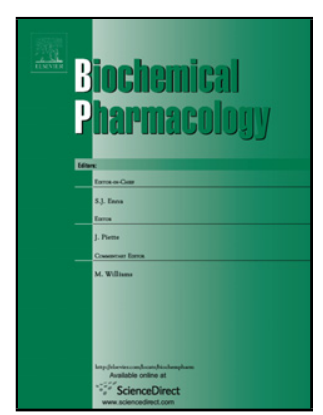

PII: S0006-2952(10)00585-X

DOI: doi:10.1016/j.bcp.2010.07.046

Reference: BCP 10680

To appear in: $\quad B C P$

Received date: $\quad 16-5-2010$

Revised date: 23-7-2010

Accepted date: $\quad$ 27-7-2010

Please cite this article as: Zoldakova M, Kornyei Z, Brown A, Biersack B, Madarász E, Schobert R, Effects of a combretastatin A4 analogous chalcone and its Pt-complex on cancer cells: a comparative study of uptake, cell cycle and damage to cellular compartments, Biochemical Pharmacology (2008), doi:10.1016/j.bcp.2010.07.046

This is a PDF file of an unedited manuscript that has been accepted for publication. As a service to our customers we are providing this early version of the manuscript. The manuscript will undergo copyediting, typesetting, and review of the resulting proof before it is published in its final form. Please note that during the production process errors may be discovered which could affect the content, and all legal disclaimers that apply to the journal pertain. 


\title{
Effects of a combretastatin A4 analogous chalcone and its \\ Pt-complex on cancer cells: a comparative study of uptake, cell cycle and damage to cellular compartments
}

\author{
Miroslava Zoldakova ${ }^{\mathrm{a}}$, Zsuzsanna Kornyei ${ }^{\mathrm{b}}$, Andreas Brown ${ }^{\mathrm{c}}$, Bernhard Biersack ${ }^{\mathrm{a}}$, \\ Emília Madarász ${ }^{\mathrm{b}}$, Rainer Schobert ${ }^{\mathrm{a},{ }^{*}}$
}

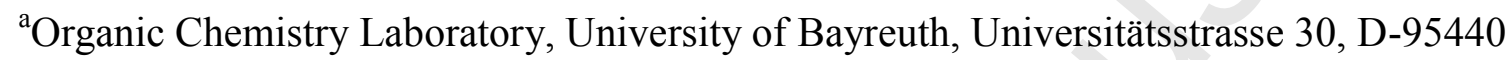
Bayreuth, Germany

${ }^{\mathrm{b}}$ Laboratory of Cellular and Developmental Neurobiology, Institute of Experimental Medicine of the Hungarian Academy of Sciences, Szigony utca 43, HU-1083 Budapest, Hungary ${ }^{\mathrm{c} C h a i r}$ of Genetics, University of Bayreuth, Universitätsstrasse 30, D-95440 Bayreuth, Germany

${ }^{*}$ Corresponding author, Organic Chemistry Laboratory, University of Bayreuth, Universitätsstrasse 30, NW 1, D-95440 Bayreuth, Germany.

Phone: +49 (0)921552679; Fax: +49 (0)921552671.

E-mail: Rainer.Schobert@uni-bayreuth.de

Supported by the Deutsche Forschungsgemeinschaft DFG (grant Scho 402/8-3).

((classification: antibiotics and chemotherapeutics)) 


\section{((Abstract))}

The combretastatin A4 analogous chalcone (2E)-3-(3-hydroxy-4-methoxyphenyl)-1-(3,4,5trimethoxyphenyl)prop-2-en-1-one $\mathbf{1}$ and its dichloridoplatinum(II) (6-aminomethylnicotinate) complex 2 were previously found to be highly active against a variety of cancer cell lines while differing in their apoptosis induction and long-term regrowth retardation (Schobert R et al. J Med Chem 2009;52:241-6) [1]. Further differences were identified now. The cellular uptake of complex $\mathbf{2}$, like that of oxaliplatin, occurred mainly via organic cation transporters (OCT-1/2; 32\%) and copper transporter related proteins $(\mathrm{Ctr} 1 ; \sim 24 \%)$, whereas that of chalcone 1 was dependent on endocytosis ( 80\%). Complex 2 was more tumourspecific than 1 concerning neural cells. This was apparent from the ratios of $\mathrm{IC}_{50}(48 \mathrm{~h})$ values against primary astrocytes versus human astroglioma cells U87 ( $>7000$ for complex 2; 55 for compound 1). In tubulin-rich neurons and 518A2 melanoma cells complex 2 disrupted microtubules and actin filaments. Cancer cells treated with 2 could repair the cytoskeletal damage but ceased to proliferate and perished. Complex 2 was particularly cytotoxic against P-gp-rich cells. It acted as a substrate for ABC-transporters of types BCRP, MRP3, and MRP1 and so was less active against the corresponding cancer cell lines. Complex 2 arrested the cell cycle of the melanoma cells in $G_{1}$ and $G_{2} / M$ phases. A fragmentation of their Golgi apparatus was observed by TEM for incubation with complex 2 but not with $\mathbf{1}$. In conclusion, unlike chalcone $\mathbf{1}$, its platinum complex $\mathbf{2}$ is highly cell line specific, is taken up via cellcontrolled transporters and induces apoptosis by triggering multiple targets.

Keywords: Chalcones; platinum; microtubules disrupting agents; melanoma 518A2 cells; organic cation transporters; Golgi apparatus. 


\section{Introduction}

Angiogenesis plays an essential role in the development and growth of solid tumours. The tumoural vascular network is characterised by peculiar irregularities and thus has been identified early on as a promising drug target. Vascular disrupting agents (VDAs) have been intensively investigated and some already went on clinical trials, mostly as combination regimens with DNA-targeting drugs [2,3]. The majority of VDAs show a pronounced affinity for tubulin and interfere with the delicate mitotic machinery of dynamic microtubule formation and destruction. The microtubular cytoskeletal fibres are crucial to mitosis and cell division, for the maintenance of cell shape and in the transport of vesicles [4]. Moreover, they are essential structural components of dendrites. In the brain, the formation of dendrites is dependent on neural activity and is mediated in part by the modulation of mictrotubule stability [5]. A good deal of the recently published VDAs are synthetic variants of longknown natural tubulin binders, e.g., combretastatin A4 (CA4) which specifically binds to the colchicine binding site of tubulin and exhibits distinct anticancer activity in vitro and in vivo [6]. Structurally related are trimethoxyphenyl chalcones [7]. The molecular mechanism of their interference with microtubules and their vascular disrupting effect is not fully understood, yet. Some studies even invoked a neuroprotective effect of chalcones [8-9]. Previously we disclosed a comparison of the effects of chalcone $\mathbf{1}$ and its platinum complex $\mathbf{2}$ on twenty-one tumour cell lines [1]. Now, we present a study of their mechanisms of action and effects in living cells.

((Figure 1 here $))$

\section{Materials and Methods}

\subsection{Reagents, materials and antibodies}

Chemicals: 3-(4,5-dimethylthiazol-2-yl)-2,5-diphenyltetrazolium bromide (MTT; ABCR, Karlsruhe, Germany), Pluronic F127, propidium iodide, calcein-AM, fumitremorgin C, 
cimetidine, wortmannin, chlorpromazine, amiloride, ouabaine (CalBiochem, Darmstadt, Germany), PageRuler ${ }^{\mathrm{TM}}$ Prestained Protein Ladder (Fermentas, St. Leon-Rot, Germany), mitoxantrone (Ralenova, Germany), RNase $10 \mathrm{mg} / \mathrm{L}$ (Qiagen, Hilden, Germany), 18\% formaldehyde (Riedel de Haen, Seelze, Germany), glycine, $1 \% \mathrm{OsO}_{4}$ in $\mathrm{H}_{2} \mathrm{O}$, N-2hydroxyethylpiperazine-N'-2-ethanesulfonic acid (HEPES; Roth), PBS buffer [8 g NaCl, 0.2 g KCl, $1.44 \mathrm{~g} \mathrm{Na}_{2} \mathrm{HPO}_{4}, 0.24$ g $\mathrm{KH}_{2} \mathrm{PO}_{4}$ per $\mathrm{L} ; \mathrm{pH}$ 7.4], $\mathrm{Pb}\left(\mathrm{NO}_{3}\right)_{2}$ (Merck), $25 \%$ glutaraldehyde, Glycider 100, propylene oxide, 2,4,6-tris(dimethlyaminomethyl)phenol (Epon; Serva), 0.5\% tannic acid (Mallinckrodt), polioform powder, uranyl acetate (Plano, Wetzlar, Germany). The chalcones $\mathbf{1}$ and $\mathbf{2}$ were synthesized according to literature $[1,10]$. Materials: 96-well filtration plates HTS (Millipore), neutral pH 7.4 gradient (Serva, 43221), Fluorobind Membrane, surface PVDF (Serva, 42571), FACS tubes (Becton Dickinson), $18 \times 18 \mathrm{~mm}$ Aclar-folia (Ted Pella), slot grids (Plano), Maco EM-Film EMS, $8.3 \times 10.2 \mathrm{~cm}$ (Maco).

Antibodies: anti-goat polyclonal OCT-1 (N-12) (Santa Cruz Biotechnology; sc-19809), antigoat polyclonal OCT-2 (C-13) (Santa Cruz Biotechnology; sc-19814), anti-mouse monoclonal alpha-tubulin (clone 12G10 from hybridoma supernatant), bovine anti-goat HRP (Santa Cruz Biotechnology; sc-2378), anti-mouse (Fab specific)-peroxidase antibody produced in goat (Sigma; A9917), glial fibrillary acidic protein (GFAP; Invitrogen), streptavidin-conjugated horseradish peroxidase (HRP; Sigma A8924), phalloidin-biotin, anti-mouse IgG Alexa 594 (A11005), anti-rabbit Alexa 594 chicken, and 4'-6-diamidino-2-phenylindole (Invitrogen), anti-mouse neuron specific $\beta$ III-tubulin (SDL3D10) and goat anti-mouse streptavidin AlexaFluor 488 conjugate (S32354) (Sigma).

\subsection{Media and cell cultures}

Media and supplements: MEM and E-MEM (Eagle's minimum essential) media were purchased from Sigma. Ham's 12, D-MEM (Dulbecco's modified eagle medium), 
NeuroBasal media, Insulin-Transferin-Selenium ITS were bought from Gibco, Invitrogen, B27 supplement, foetal calf serum (FCS), antibiotic-antimycotic solution, gentamycin, $3 \mathrm{mM}$ retinoic acid, 10\% polylysine, and glutamine from Gibco-BRL-Life.

Cell cultures: Human 518A2 melanoma cells were obtained from the department of oncology and hematology of the Martin-Luther-University, Halle, and cultured in D-MEM with 10\% FBS, $0.55 \%$ antibiotic-antimycotic solution and $0.3 \%$ gentamycin. Cervix carcinoma $\left(\mathrm{KBvl}^{+\mathrm{Vbl}}\right)$ and breast carcinoma $\left(\mathrm{MCF}-7^{+\mathrm{Top}}\right)$ cells were a gift from the department of pharmacy, University of Regensburg. The $\mathrm{KBv} 1 / \mathrm{KBv}^{+\mathrm{Vbl}}$ cells were used from $90^{\text {th }}-118^{\text {th }}$ passage and cultured in D-MEM with 10\% FBS, 0.55\% antibiotic-antimycotic solution and $0.3 \%$ gentamycin, without/with $340 \mathrm{nM}$ vinblastine [11]. The MCF-7/MCF- $7^{+\mathrm{Top}}$ cells $\left(160^{\text {th }}-\right.$ $180^{\text {th }}$ passage) were grown in E-MEM supplemented with $5 \%$ FBS, without/with $550 \mathrm{nM}$ topotecane [11]. The human colon adenocarcinoma cells $\left(\right.$ HT-29/HT-29 $9^{+ \text {Colc }} ; 11^{\text {th }}-16^{\text {th }}$ passage) were cultured in RPMI medium supplemented with 5\% FBS, without/with $62.5 \mathrm{nM}$ colchicine. Neural cells used: NE-4C neuroectodermal stem cells NE-4C, primary mouse astrocytes [13,14], glioma cell lines: rat glioma C6 [ATCC No.: CCL-107] and human astroglioma U87 [ATCC No.: HTB-14], non-neural mouse fibrosarcoma cells WEHI 164 [12]. Cells were maintained under a moisture-saturated atmosphere $\left(95 \%\right.$ humidity, $\left.5 \% \mathrm{CO}_{2}\right)$ at $37{ }^{\circ} \mathrm{C}$ in $75 \mathrm{~mL}$ culture flasks (Nunc, Germany). They were serially passaged using $0.05 \%$ trypsin / 0.02\% EDTA (PAA Laboratories, Cölbe, Germany).

\subsection{Inhibition of cancer cell growth (MTT assay)}

MTT was used to identify viable cells which reduce it to a violet formazan [15]. The cells $\left(1 \times 10^{5}\right.$ cells $\left./ \mathrm{mL}\right)$ were cultured for $12-24 \mathrm{~h}$ depending on growth progress. Incubation $(5 \%$ $\mathrm{CO}_{2}, 95 \%$ humidity, $37{ }^{\circ} \mathrm{C}$ ) of the cells following treatment with the test compounds dissolved in DMF (dilution series ranging from 0.01 to $50 \mu \mathrm{M}$ in medium) was continued for $24 \mathrm{~h}$ or $48 \mathrm{~h}$. Blank and solvent controls were treated identically. Then a $1.25 \mathrm{mg} / \mathrm{mL}$ stock 
solution of MTT in phosphate buffered saline was added to a final MTT concentration of $0.125 \mathrm{mg} / \mathrm{mL}$. After $2 \mathrm{~h}$ the formazan precipitate was dissolved in a $10 \%$ solution of sodium dodecylsulfate (SDS) in DMSO containing $0.6 \%$ acetic acid. For the neural cells the formazan was dissolved in acidified $(0.08 \mathrm{M} \mathrm{HCl})$ isopropanol and measured immediately. The absorbance at $570 \mathrm{~nm}$ and $630 \mathrm{~nm}$ was measured with an automatic microplate reader (MWGBIOTECH/BioRad). All experiments were carried out at least in triplicate; the percentage of viable cells was calculated as the mean \pm SD relative to controls set to $100 \%$.

\subsection{Cellular uptake of drugs into 518 A2 melanoma cells}

Routes of uptake of the test compounds were assessed by measuring their cytotoxicity against 518A 2 melanoma cells in the presence of specific inhibitors by MTT assays. The cells $\left(5 \times 10^{5}\right.$ cells $/ \mathrm{mL}$ ) were grown on 96-well filtration plates. After $24 \mathrm{~h}$ inhibitors were applied to final concentrations of $0.5 \mathrm{mM}$ cimetidine, or $0.1 \mathrm{mM}$ tetraethlyammonium (TEA), or $10 \mathrm{nM}$ wortmannin, or $14 \mu \mathrm{M}$ chlorpromazine, or $10 \mu \mathrm{M}$ amiloride, or $5 \mu \mathrm{M}$ ouabaine. The 518A2 cells were pre-incubated with these inhibitors for $15 \mathrm{~min}$ and then treated with $100-200 \mu \mathrm{M}$ of chalcones 1 or 2 or reference compounds. After 3.5 h cell vitality was measured by MTT tests. The insoluble formazan crystals were washed with distilled water, dissolved in DMSO and the absorbance of the resulting filtered solution was measured. The difference of absorbances at 570 and $630 \mathrm{~nm}$ was calculated relative to controls of untreated cells and cells treated with inhibitors. The cytotoxicity of the test compounds was validated by comparison with their effects in cells not treated with an inhibitor and with the net effect of the respective inhibitor in cells not exposed to the test compounds.

\subsection{Western blot analysis of organic cation transporters}

Cells were collected by centrifugation, suspended in an SDS-PAGE sample buffer, sonicated to shear genomic DNA and boiled at $95{ }^{\circ} \mathrm{C}$ for $15 \mathrm{~min}$. The resulting cell suspension was passed through a 27-gauge needle. The combined extracts were separated on a gradient SDS- 
PAGE gel and transferred to a PVDF membrane. The individual proteins were detected by means of anti-goat polyclonal OCT-1 (N-12) (sc-19809), anti-goat polyclonal OCT-2 (C-13) (sc-19814) and anti-alpha-tubulin (12G10 mouse monoclonal from hybridoma supernatant) primary antibodies and appropriate secondary antibodies conjugated with HRP.

\subsection{Drug efflux from KBv1 and MCF-7 carcinoma cells}

\subsubsection{Calcein-AM assay for p-glycoprotein activity of $K B v 1 / K B v 1^{+V b l}$ cells}

The assay was carried out with slight modifications according to a literature procedure [16]. Briefly, $\mathrm{KBv1} / \mathrm{KBv1}^{+\mathrm{Vbl}}$ cells were trypsinised 3 or $4 \mathrm{~d}$ after passaging and washed with PBS at $25{ }^{\circ} \mathrm{C}$. Cells $\left(1.3 \times 10^{6} / \mathrm{mL}\right)$ were resuspended in $0.75 \mathrm{~mL}$ of Ca-buffer [120 mM NaCl, 5 $\mathrm{mM} \mathrm{KCl}, 2 \mathrm{mM} \mathrm{MgCl}{ }_{2} \times 6 \mathrm{H}_{2} \mathrm{O}, 1.5 \mathrm{mM} \mathrm{CaCl}_{2} \times 2 \mathrm{H}_{2} \mathrm{O}, 125 \mathrm{mM}$ HEPES, $10 \mathrm{mM}$ glucose, $\mathrm{pH}$ 7.4] and $0.25 \mathrm{~mL}$ of Cs-buffer [2\% BSA in $1 \mathrm{~mL}$ Ca buffer, $5 \mu \mathrm{L}$ of Pluronic F127 $(20 \%$ in DMSO)] was added. The samples were mixed with $50 \mu \mathrm{M}$ of test substances, shortly vortexed and incubated for $15 \mathrm{~min}$. Calcein-AM was added to achieve a concentration of $1 \mu \mathrm{M}$. After incubation $\left(10 \mathrm{~min}, 37^{\circ} \mathrm{C}, 5 \% \mathrm{CO}_{2}\right)$, and centrifugation $\left(800 \mathrm{rpm}, 5 \mathrm{~min}, 4{ }^{\circ} \mathrm{C}\right)$ a cell pellet was obtained which was rinsed once with ice-cold PBS and re-suspended in $0.5 \mathrm{~mL}$ of Cabuffer. The fluorescence of calcein $\left(\lambda_{\mathrm{Ex}}=485 \mathrm{~nm}, \lambda_{\mathrm{Em}}=535 \mathrm{~nm}\right)$ was measured in a black microplate on a TECAN Infinite F200 plate reader and the data were analysed and calculated relative to verapamil as a positive control.

\subsubsection{Mitoxantrone assay for BCRP activity of $M C F-7 / M C F-7^{+T o p}$ cells}

The assay was carried out according to a modified literature procedure [11]. MCF-7 ${ }^{+\mathrm{Top}}$ cells were incubated with $20 \mu \mathrm{M}$ mitoxantrone in $70 \%$ ethanol and briefly vortexed. $10 \mu \mathrm{M}$ of test compounds 1 or $\mathbf{2}$ in DMF were added to allow maximal mitoxantrone uptake into the cells over a period of $30 \mathrm{~min}$ at $37{ }^{\circ} \mathrm{C}$. After centrifugation $\left(800 \mathrm{rpm}, 5 \mathrm{~min}, 4{ }^{\circ} \mathrm{C}\right)$ the cells were washed twice with PBS, pipetted into a black microplate together with the positive control fumitremorgin C (FTC) and the negative control DMF. The plates were immediately placed in 
a TECAN fluorescence plate reader and mitoxantrone fluorescence was measured at $620 \mathrm{~nm}$ excitation and $670 \mathrm{~nm}$ emission wavelengths. Three wells of each plate contained the internal standard FTC $(10 \mu \mathrm{M})$. Its cellular fluorescence was taken as a measure of $100 \%$ BCRP inhibition.

\subsection{Time-lapse microscopy}

Cells were grown on IBIDI dishes in a custom-made microscope stage incubator $\left(37^{\circ} \mathrm{C}, 5 \%\right.$ $\mathrm{CO}_{2}$ ). Time-lapse recording was performed with a computer-controlled Zeiss Axiovert 200M microscope equipped with 10- and 20-fold objectives and an AxioCam MRm digital camera.

\subsection{Immunocytochemistry}

The cells (518A2 melanoma, astroglia) grown on poly- $L$-lysine-coated glass cover slips were fixed with 4\% paraformaldehyde in PBS for $20 \mathrm{~min}$ at room temperature and then permeabilised with Triton X-100 $(0.1 \% \mathrm{v} / \mathrm{v}$ in PBS; $5 \mathrm{~min})$. Nonspecific antibodies were blocked by incubation with 3\% FBS in PBS (room temperature, $1 \mathrm{~h}$ ). a-GFAP antibody (rabbit, DAKO) was used in a dilution of 1:2000 and was visualized by anti-rabbit IgG Alexa 594 (1:1000). Phalloidin-biotin was applied in 1:1000 dilution followed by avidin-Alexa 488 (1:800). Fluorescence images were captured manually on a Zeiss Axiovert 200M microscope fitted with 20-60 fold zoom and a Zeiss AxioCam MRm digital camera.

\subsection{Cell cycle analysis}

518A2 melanoma cells $\left(10^{6}\right)$ were treated with the test compounds, positive $(250 \mu \mathrm{g} / \mathrm{mL}$ nocodazole) / negative (DMF) controls and then harvested at certain time intervals. The cells were washed, re-suspended in $200 \mu \mathrm{L}$ PBS, and incubated with $8 \mathrm{~mL}$ of $70 \%$ ice-cold ethanol for fixation. They were centrifuged, washed with PBS, and re-suspended in $1 \mathrm{~mL}$ of a PBS solution of $3.8 \mathrm{mM}$ sodium citrate and $50 \mu \mathrm{g} / \mathrm{mL}$ propidium iodide with freshly added RNase [17]. After $1 \mathrm{~h}$ incubation at $37^{\circ} \mathrm{C}$ the concentration of double-stranded DNA in the samples 
was determined by measuring the emission $(570 \mathrm{~nm})$ of its fluorescent adducts excited at 488 nm, using a Beckman CYTOMICS FC 500 cytometer.

\subsection{Transmission electron microscopy}

518A2 melanoma cells were plated on pieces of aclar film, grown for $24 \mathrm{~h}$, exposed for 20 min to $100 \mu \mathrm{M}$ of either compound $\mathbf{1}$ or $\mathbf{2}$ and flat-embedded for transmission electron microscopy as follows. Cells were fixed in $0.1 \mathrm{M}$ HEPES, $4 \mathrm{mM} \mathrm{CaCl}{ }_{2}$ containing $2.5 \%$ glutaraldehyde, $\mathrm{pH} \mathrm{7.2,} \mathrm{for} 4 \mathrm{~h}$ at room temperature. After three rinses with $0.1 \mathrm{M}$ HEPES, 4 $\mathrm{mM} \mathrm{CaCl}{ }_{2}, \mathrm{pH} 7.2$, cells were postfixed with $1 \%$ osmium tetroxide in distilled water for 45 min at $4{ }^{\circ} \mathrm{C}$, rinsed three times in distilled water and incubated in $1 \%$ uranyl acetate in distilled water for $1 \mathrm{~h}$ at $4{ }^{\circ} \mathrm{C}$. Dehydration of the samples in an ethanol series, infiltration with Epon, and flat embedding was performed according to standard procedures. Ultra-thin sections $(60-70 \mathrm{~nm})$ were cut and mounted on pioloform-coated copper grids. Sections were stained with uranyl acetate and lead citrate [18] and viewed with a Zeiss CEM 902 transmission electron microscope at $80 \mathrm{kV}$. Micrographs were taken using EMS EM film.

\section{Results}

\subsection{Cytotoxicity studies with selected cell lines}

Neural cells. Chalcones target tubulin and microtubules [19]. We analysed the relative cytotoxicities of chalcones 1 and 2 against tubulin-rich cells of neural origin (Table 1; grey rows). Normal mouse astroglia were not particularly sensitive to chalcone $\mathbf{1}$ and virtually insensitive to platinum complex 2 during the whole $48 \mathrm{~h}$ incubation period. However, human U87 glioma cells responded well upon prolonged exposure to both compounds, and especially well to the Pt-complex 2 at an $\mathrm{IC}_{50}(48 \mathrm{~h}) \sim 140 \mathrm{nM}$. Primary neurons were also sensitive to a prolonged treatment. Both chalcones were strongly cytotoxic against C6 rat glioma cells with $\mathrm{IC}_{50}(48 \mathrm{~h}) \sim 150-170 \mathrm{nM}$ and also against NE-4C cells derived from the fore- and midbrain vesicles of p53-deficient 9-day-old mouse embryos [20] after exposure for 48 h. WEHI 164 
fibrosarcoma cells, included for reasons of comparison, were equally susceptible to chalcone $\mathbf{1}$ and its platinum complex 2.

ABC-transporter-rich tumour cells. ABC-transporters pump drugs out of cancer cells and are responsible for chemoresistance. Their interference with compounds $\mathbf{1}$ and $\mathbf{2}$ was investigated by using various non-neural cancer cells rich in these transporters such as MCF-7 breast, KBv1 cervix and HT-29 colon carcinomas (Table 1; bottom half). These cells had been grown in the presence of specific substrates of their transporters to stimulate their overexpression. Human 518A2 melanoma cells served as reference cells not overexpressing any ABCtransporters. By long-term exposure to topotecane resistant MCF- $7^{+ \text {Top }}$ cells overexpressing exclusively BCRP (breast cancer resistance protein) were obtained. Chalcone $\mathbf{1}$ was cytotoxic in these MCF- $7^{+\mathrm{Top}}$ cells with $\mathrm{IC}_{50}(24 \mathrm{~h} / 48 \mathrm{~h}) \sim 12 / 1 \mu \mathrm{M}$. It showed the same $\mathrm{IC}_{50}$ value in the wild type MCF-7 cells after $24 \mathrm{~h}$, which remained constant for up to $48 \mathrm{~h}$. In comparison with chalcone 1 its Pt-complex 2 exhibited a distinctly lower activity in both MCF-7 cell lines. Resistant $\mathrm{KBv1}^{+\mathrm{Vbl}}$ cells overexpressing P-gp were obtained by treating the wild type cells with vinblastine. The chalcones $\mathbf{1}$ and $\mathbf{2}$ were highly and comparably efficacious against both cell lines with a slight edge for the latter. HT-29 cells feature a high amount of multiresistance protein 3 (MRP3) and a low amount of MRP1. When treated with colchicine HT29 cells shift this ratio by overexpressing MRP1 and cutting back on MRP3 [21]. Both test compounds were little active in either HT-29 cell line but distinctly more so in the HT-29+Colc cells. A similar trend was observed also for cisplatin (data not shown). According to literature [21] colchicine-induced overexpression of MRP1 is accompanied by a changed sphingolipid composition.

((Table 1 here $))$

\subsection{Cellular uptake of chalcones $\mathbf{1}$ and $\mathbf{2}$}


In order to ascertain whether the chalcone $\mathbf{1}$ or its platinum complex $\mathbf{2}$ enter the cell via specific transporters or by endocytosis, a simple temperature-dependent experiment was performed. The process of endocytosis is known to be virtually halted at temperatures below $16^{\circ} \mathrm{C}[22,23]$. Almost twice as many 518A2 melanoma cells survived exposure to $100 \mu \mathrm{M}$ of 1 at $4{ }^{\circ} \mathrm{C}$ when compared to $37^{\circ} \mathrm{C}$ ( $c f$. Supplementary Data), which is an indication of this chalcone being taken up mainly via endocytosis. In contrast, the paused endocytosis process did not affect the cytotoxicity of platinum complex 2 , which left ca $40 \%$ cells alive at either temperature. Alternative ways for the entry of platinum complexes into cells involve copper related transport proteins (Ctr1) and organic cation transporters (OCT-1/2). Gust et al. studied their relevance by switching off individual transporters with specific inhibitors [24]. Earlier on, the accumulation of cisplatin by a high-affinity copper transporter Ctr1 had been found to compete with that of copper [25]. The OCT convey positively charged substances and may be inhibited by cimetidine (inhibitor) or by tetraethylammonium chloride (TEA; competitor). Endocytotic processes depending on a sodium gradient can be slowed down by adding ouabaine, an inhibitor of the $\mathrm{Na}^{+} / \mathrm{K}^{+}$pump [26]. Macropinocytosis, a distinct form of endocytosis, depends on a $\mathrm{Na}^{+} / \mathrm{H}^{+}$exchanger that can be blocked by amiloride $[24,27]$. The enzyme phosphatidylinositol 3-kinase that plays a central role in the down-stream signalling cascade associated with macropinocytosis by F-actin microfilament re-arrangement, can be inhibited by the fungal metabolite wortmannin [28]. Clathrine-mediated endocytosis can be blocked by chlorpromazine [29]. We now examined the influence of all these inhibitors on the uptake of chalcones 1 and $\mathbf{2}$ into 518A2 melanoma cells. To this end, the cells were preincubated with non-toxic concentrations of the respective inhibitors for $15 \mathrm{~min}$ before the chalcones were added and their cytotoxicities were measured by the usual MTT assay. Figure 2 illustrates the effects of the individual inhibitors on the cytotoxicity of chalcone $\mathbf{1}$ (grey bars) and complex 2 (black bars) against 518A2 cells and so indirectly also the share that the 
various transport pathways blocked by these inhibitors have in the uptake of $\mathbf{1}$ and $\mathbf{2}$. Treatment of the cells with $100 \mu \mathrm{M}$ chalcone 1 in the absence of any inhibitors for $3.5 \mathrm{~h}$ left $40 \%$ of the cells vital. Pre-incubation with $5 \mu \mathrm{M}$ ouabaine attenuated the cytotoxicity of 1 by ca. $40 \%$ so as to leave $66.5 \pm 5 \%$ of the cells alive. In other words, ca. $40 \%$ of chalcone 1 were accumulated by the cells via $\mathrm{Na}^{+} / \mathrm{K}^{+}$-dependent endocytosis. Addition of $10 \mu \mathrm{M}$ amiloride led to $55 \pm 2 \%$ of the cells surviving. This corresponds to ca. $24 \%$ uptake of 1 via $\mathrm{Na}^{+} / \mathrm{H}^{+}$pump driven macropinocytosis. Addition of $14 \mu \mathrm{M}$ chlorpromazine resulted in ca. $50 \%$ of the cells remaining vital, which speaks for $18 \%$ of the chalcone being taken up through clathrine-mediated endocytosis. $10 \mathrm{nM}$ wortmannin decreased the percentage of vital cells after exposure to 1 to $48 \pm 3 \%$, indicating 13\% contribution from PI3-kinase associated macropinocytosis in the accumulation of chalcone 1. Interestingly, the inhibitory effect of wortmannin was time-dependent and most pronounced at the beginning (1-2 h) of the incubation with 1. All these inhibitors interfere with endocytosis processes. A possible explanation is that $518 \mathrm{~A} 2$ cells are mTOR positive and that PI3-K/Akt-signalling regulates mTOR activity. Hence, any inhibition of PI3 kinase might postpone the cytotoxic effect of $\mathbf{1}$. Inhibition of the OCT and Ctr1 had little influence (2-3\%) on the cytotoxicity of 1 . Complex 2 was accumulated by 518A2 cells differently from the parent chalcone 1 . If administered without any inhibitors added, $200 \mu \mathrm{M}$ concentrations of complex 2 were necessary to reduce the number of viable cells to $40 \pm 2 \%$ as in the case of 1 . Addition of $5 \mu \mathrm{M}$ of the $\mathrm{Na}^{+} / \mathrm{K}^{+}-$ ATPase pump inhibitor ouabaine decreased the cytotoxicity of 2 by $24 \%$. Clathrine-dependent endocytosis contributed ca. $14 \%$ to the uptake of complex 2 as shown by a reduction of the cytotoxicity to the effect of $50 \pm 3 \%$ viable cells upon addition of $14 \mu \mathrm{M}$ inhibitor chlorpromazine. Uptake of 2 via $\mathrm{Na}^{+} / \mathrm{H}^{+}$pump driven macropinocytosis seemed to play no role. Cell entry of complex 2 took place mainly via OCT-1/2 (32\%) as shown by an increase 
of viable cells to ca. $61 \%$ upon addition of $500 \mu \mathrm{M}$ cimetidine and via $\mathrm{Ctr} 1(20 \%)$ as the addition of $8 \mathrm{nM} \mathrm{CuCl}_{2}$ increased the percentage of viable cells to ca. $55 \%$.

((Figure 2 here))

\subsection{Western blot analysis of organic cation transporters}

Evidence for the presence in 518A2 melanoma and $\mathrm{KBv1}^{+\mathrm{Vbl}}$ cervix carcinoma cells of organic cation transporters hOCT-1 and hOCT-2 that belong to the solute carrier subfamily SLC22A of membrane transport proteins was provided by westernblotting. More than one band were visible upon staining with a primary antibody for hOCT-1 (= SLC22A1) since it recognises the $\mathrm{N}$-terminus of this protein which is a highly conserved segment also present in OCT-2. In addition, several isoforms of hOCT-1 are known. We could assign the band corresponding to a protein of size $\sim 54 \mathrm{kDa}$ to hOCT-1. Staining of the membrane with an antibody specific for the C-terminus of hOCT-2 (= SLC22A2), which differs considerably from the C-terminus of hOCT-1, rendered a single intense band for this protein of size $\sim 30$ $\mathrm{kDa}$. This band had also been visible upon staining with the less specific OCT-1 antibody. Although the abundance of hOCT-1/2 in tumour cells in general had been frequently proposed [30], this is the first experimental evidence for their occurrence in the said two cancer cell lines.

((Figure 3 here))

\subsection{Interference with $A B C$ transporters}

We investigated whether chalcones $\mathbf{1}$ and $\mathbf{2}$ interact with drug transport proteins of types ABCB1 (P-gp) [31-33] or BCRP [34] in a substrate- or inhibitor-like fashion. P-gp overexpressing $\mathrm{KBv}^{+\mathrm{Vbl}}$ cervix carcinoma cells [35] alongside their wild type parent cells were treated with chalcones 1 and $\mathbf{2}$ in the presence of calcein-AM (Fig. 4a). The inhibition of P-gp allows for calcein-AM taken up by the cells to get cleaved with formation of fluorescent calcein. As a positive control, the fluorescence intensity of $\mathrm{KBv}^{+\mathrm{Vbl}}$ cells treated with $50 \mu \mathrm{M}$ 
of the clinically established chemosensitiser verapamil $[35,36]$ was set to $100 \%$. Surprisingly, wild type KBv1 cells under the same conditions reached only $\sim 45 \%$ of calcein fluorescence of the resistant $\mathrm{KBv}^{+\mathrm{Vbl}}$ cells. Possibly, they have other ways at their disposal to eliminate calcein-AM or calcein, which is not without precedence [37,38]. Calcein fluorescence in KBv1 cells was also relatively low in the absence of verapamil. Treatment with chalcone $\mathbf{1}$ led to almost the same absolute fluorescence intensity of calcein in either, resistant and wild type cell line. In contrast, Pt-complex $\mathbf{2}$ was more effective than chalcone $\mathbf{1}$ in the resistant cells. Relative to the fluorescence in the presence of verapamil, complex $\mathbf{2}$ caused an identical decrease of calcein fluorescence in $\mathrm{KBv} 1$ and $\mathrm{KBv} 1^{+\mathrm{Vbl}}$ cells. MCF-7 breast carcinoma cells express BCRP drug transporters and when treated with topotecane $(550 \mathrm{nM}$ over 40 generations) turn multi-drug resistant overexpressing this protein $\left(\mathrm{MCF}-7^{+ \text {Top }}\right.$ cells). The mitoxantrone assay is based on the active export through BCRP of the fluorescent mitoxantrone, accumulated by the cells via diffusion. The effects of chalcones $\mathbf{1}$ and $\mathbf{2}$ on the fluorescence of intracellular mitoxantrone in $\mathrm{MCF}-7$ and $\mathrm{MCF}-7^{+\mathrm{Top}}$ cells relative to that of the specific BCRP inhibitor fumitremorgine C [39] and to a negative control of cells treated only with mitoxantrone are shown in Fig. 4b. Both compounds gave rise to a doubling of the mitoxantrone fluorescence in either cell line relative to the negative control and so are likely to be competitive substrates for the BCRP proteins with the free chalcone $\mathbf{1}$ having a slightly greater binding affinity than its complex $\mathbf{2}$.

((Figure 4 here) $)$

\subsection{Time-lapse microscopy}

Neurons are particularly rich in tubulin and so are well suited to test agents affecting microtubule organisation. Their regular growth requires microtubules being transported plus ends first from the cell body all the way down into the axon [40]. The effect of chalcones 1 and $\mathbf{2}$ on the structure, development and movement of a network of rat neurons was now 
monitored by time-lapse microscopy [41]. Neurons treated with $10 \mu \mathrm{M}$ of the test compounds showed a retraction of their processes back to the soma within 30 minutes (Fig. 5, top). The cells got closer to each other with their bodies swelling and aggregating. Most of the neural network lost its integrity and processes were disconnected from the cell bodies of adjacent neurons. However, exposure to Pt-complex 2 caused only an incomplete disruption of the networks. An analogous experiment was performed with 518A2 melanoma cells, which were initially tightly attached as a monolayer to the surface of the mini Petri dish. Overall, dynamics and motility of untreated cells was slow as they underwent merely negligible morphological changes. Only a few cells detached from the monolayer within the first two hours. In contrast, exposure of 518A2 cells to chalcone 1 led to an immediate rounding and an enhancement of motility and cell shrinking dynamic (Fig. 5, bottom). A very similar behaviour of 518A2 cells, delayed by 2 min, was observed upon incubation with complex 2 . The cells readily dissociated from the monolayer with their form turning from flat to spherical ( $c f$. movies as supplementary files in the online version).

((Figure 5 here $))$

\subsection{Immunocytochemistry of actin filaments in astrocytes and $518 A 2$ cells}

An immunocytochemical analysis of the morphological changes of the actin filaments of astrocytes initiated by the chalcones $\mathbf{1}$ and $\mathbf{2}$ was carried out and compared with the behaviour of 518A2 melanoma cells. Antibodies to astrocyte-specific GFAP intermediate filaments (glial fibrillary acidic protein) were employed to visualise the astroglial cells and phalloidin labelling was used to identify actin filaments. The micrographs showed that both types of filaments, actin (in green) and GFAP (in red), were disintegrated upon treatment with the test chalcones, most pronouncedly the actin filaments near the cell membrane. The GFAP filaments shrank only in the vicinity of the cell nuclei, which remained unaffected. Figure 6 shows typical effects of chalcone $\mathbf{1}$ on astrocytes. Results with complex $\mathbf{2}$ were similar. 
Likewise, fluorescence micrographs of immunostained 518A2 cells revealed a significant breakdown of the actin network when treated with chalcones 1 or 2 (Fig. 7).

((Figures 6 and 7 here))

\subsection{Cell cycle analysis}

While cisplatin is known to generally arrest cells in the G1 phase due to cross-link interaction with DNA [42] chalcone, 1,3-diphenylpropenone, arrests cells of the human T24 and HT1376 bladder cancers in the G2/M phase [43]. We now assessed the cell cycle progression of melanoma 518A2 cells treated with chalcones $\mathbf{1}$ and $\mathbf{2}$ by FACS analysis after DNA staining with propidium iodide (Fig. 8 and Supplementary Data). 63\% of untreated 518A2 cells were in G1 phase, $24 \%$ in $\mathrm{S}$ phase and 13\% in G2/M phase after $18 \mathrm{~h} .518 \mathrm{~A} 2$ cells treated with 250 $\mu \mathrm{g} / \mathrm{L}$ nocodazole, a synthetic analogue of taxol, were mainly in sub-G1 phase after $18 \mathrm{~h}$, a shorter $12 \mathrm{~h}$ exposure led to $76 \%$ of the cells being in G2/M phase. $10 \mu \mathrm{M}$ of chalcone 1 had a similar effect arresting $61 \%$ in $\mathrm{G} 2 / \mathrm{M}$ phase after $18 \mathrm{~h}$ incubation. 518A2 cells treated with 10 $\mu \mathrm{M}$ of Pt-complex 2 had their cell cycle mainly arrested in G2/M phase (59\%) as is typical for chalcones, but atypically numbers of cells in G1 phase increased as well (19\%). 22\% of the cells were in the $\mathrm{S}$ phase. To dismiss a conceivable hydrolytic cleavage of $\mathbf{2}$ during incubation, we also proved that $100 \mu \mathrm{M}$ of dichlorido(6-aminomethylnicotinic acid)platinum(II), the assumed hydrolysis product of ester $\mathbf{2}$, had no effect on the cell cycle at all. As a positive control, treatment with cisplatin led to $69 \%$ of 518 A 2 cells being arrested in G1 phase.

((Figure 8 here $))$

\subsection{Transmission electron microscopy}

For a visualisation of morphological effects 518A2 melanoma cells were treated with $100 \mu \mathrm{M}$ 1 or 2 for $15 \mathrm{~min}$, kept under medium for another hour, then embedded and finally viewed with a transmission electron microscope (TEM). While untreated control cells appeared prolate and undifferentiated with filopodia for cell attachment on the rim, the cells incubated 
with the chalcones $\mathbf{1}$ or $\mathbf{2}$ adopted a rounded shape. A similar morphological change had been reported for H460 non-small cell lung cancer cells treated with CA4 [44]. In addition, the treated 518A2 cells had blebs emerging on their surface ( $c f$. Supplementary Data). Stress fibres were also observed in the treated cells (Fig. 9h). Multivesicular bodies and autophages (Fig. 10b) with double membranes were visible in most of the analysed cells (Fig. 9f). Control cells and treated cells also differed with respect to the state of their mitochondria, centrioles and Golgi apparatus (GA). Mitochondrial populations consist mainly of short and long tubules, which constantly migrate along microtubule tracks [45]. Any disruption of the microtubules/actin skeleton, e.g., by treatment with chalcones $\mathbf{1}$ or $\mathbf{2}$ should severely affect the mitochondrial trafficking and cause mitochondrial disorganisation. We found that mitochondria of cells treated with the chalcones were highly condensed and localised mainly at the apical side of the cells. They frequently displayed dislocated inner membranes (Fig. 9e). Only a small percentage of the untreated control cells were found in G2/M phase with visible centrioles. After treatment with the chalcones, many cells had visible pro-centrioles (Fig. 9c), which is an indication of them being arrested in G2/M phase. The GA undergoes irreversible fragmentation during apoptosis in part as a result of caspase-mediated cleavage of several Golgi-associated proteins. A fragmentation of the GA was observed mainly in 518A2 cells treated with complex 2 (Fig. 10b) but not with chalcone $\mathbf{1}$.

((Figures 9 and 10 here))

\section{Discussion}

The in vitro cytotoxicities of the chalcones $\mathbf{1}$ and $\mathbf{2}$ vary by a factor of 200 for the different cell lines tested. Moreover, individual cell lines show different sensitivities to the chalcones $\mathbf{1}$ and 2 suggesting distinct and incongruent mechanisms by which these compounds act. The large spread between the $\mathrm{IC}_{50}(48 \mathrm{~h})$ of non-malignant astroglia $(100 \mu \mathrm{M})$ and $\mathrm{U} 87$ glioma cells $(140 \mathrm{nM})$ in the case of Pt-complex 2 is pharmacologically interesting and a significant 
improvement over parent chalcone 1 . The platinum complex is also less well expelled by cells overexpressing P-gp when compared to the unmetallated chalcone. The results of the calceinAM assays showed that it inhibits the efflux functionality of P-gp by acting as a genuine inhibitor or a modulator. As a consequence, complex $\mathbf{2}$ is more efficacious in multidrug resistant cancer cells featuring this particular $\mathrm{ABC}$-transporter, e.g., $\mathrm{KBv}^{+\mathrm{Vbl}}$. Despite their similar chemical structures the test compounds are taken up by cells via different pathways. While chalcone $\mathbf{1}$ is preferentially accumulated by endocytosis its platinum complex $\mathbf{2}$ is taken up mainly via the organic cation and copper related transporters. Insofar, complex 2 resembles oxaliplatin which was shown by Lippard et al [46] to be an excellent substrate for the human organic cation transporters OCT-1 and OCT-2. Both chalcones 1 and 2 vigorously depolymerised microtubules and actin filaments in neural and cancer cells. They proved equally effective in damaging mitochondria and in arresting cancer cells in G2/M phase. However, only complex 2 led to an accumulation of cells in G1 phase, reminiscent of the effect of cisplatin. Hence, complex 2 has a dual impact on the cell cycle of 518A2 melanoma cells by combining the effects of Pt-complexes and of chalcones in general. However, the DNA binding activity of $\mathbf{2}$ was found to be four times lower than that of the good DNAbinder cisplatin [1]. This could explain the lower number of cells arrested in G1 phase upon treatment with 2. Morphologically, both test compounds led to a rounding and detachment of 518A cells and an enhancement of their motility and cell shrinking dynamic. This behaviour is in line with the generally accepted mechanisms of tubulin binding agents (TBAs) [3] involving activation of RhoA/RhoA kinase, an intracellular coordinator of cytoskeletal rearrangement of microtubules and actin. In our experiment with $\mathbf{1}$ and $\mathbf{2}, 518 \mathrm{~A} 2$ cells were able to repair the shrinkage effects and most of them spread again after three hours. The results from the transmission electron microscopy of 518A2 cells treated with the compounds $\mathbf{1}$ and $\mathbf{2}$ are also in keeping with their effects on the cell cycle. The occurrence of centrioles as 
a result of aberrant chromosome segregation could be due to DNA damage (possibly in tandem with defective checkpoints) or to a destabilisation of the spindle apparatus $[44,47]$. Maintenance of the microtubule integrity plays a pivotal role in stabilising the pericentriolar matrix. Our observation is consistent with the notion that the microtubule depolymerising effect of both chalcones $\mathbf{1}$ and $\mathbf{2}$ leads to a mitotic catastrophe and thus to an arrest in G2/M phase. A similar mitotic failure had been reported for H460 NSCLC cells treated with CA4 [44]. Moreover, complex 2 but not chalcone 1 initiated the fragmentation of the Golgi apparatus of 518A2 melanoma cells. This fragmentation is an early event that occurs independently of major changes to the actin and tubulin cytoskeleton [48].

Thus, the observed differences in the anticancer activities of the free chalcone $1 v s$. its platinum complex 2 could be traced back to distinct differences in the biochemistry of their uptake, clearance and impact on the cell cycle and on cellular components. Complex 2 apparently combines some modes of action of chalcones and platinum complexes and so can address more cancer-relevant targets than parent chalcone $\mathbf{1}$.

\section{Acknowledgement}

We thank the Deutsche Forschungsgemeinschaft for financial support (grant Scho 402/8-3).

We are grateful to Dr. S. Geimer, D. Scholz and M. Fischer from the Electron Microscopy Laboratory (Biology) for expert help with electron microscopy and to Prof. O. Stemmann from the Genetics department for help with cell cycle analysis.

\section{Appendix A. Supplementary data}

Supplementary data and two movies associated with this article can be found, in the online version, at doi..

\section{References}

1 Schobert R, Biersack B, Dietrich A, Knauer S, Zoldakova M, Fruehauf A, Mueller T. $\mathrm{Pt}(\mathrm{II})$ complexes of a combretastatin A-4 analogous chalcone: effects of conjugation on 
cytotoxicity, tumor specificity, and long-term tumor growth suppression. J Med Chem 2009;52:241-6.

2 Kanthou C, Tozer GM. Microtubule depolymerizing vascular disrupting agents: novel therapeutic agents for oncology and other pathologies. Int J Exp Pathol 2009;90:284-94.

3 Lippert JW. Vascular disrupting agents. Bioorg Med Chem 2007;15:605-15.

4 Vantard M, Cowling R, Delichere C. Cell cycle regulation of the microtubular cytoskeleton. Plant Mol Biol 2000;43:691-703.

5 Vaillant AR, Zanassi P, Walsh GS, Aumont A, Alonso A, Miller FD. Signaling mechanisms underlying reversible, activity-dependent dendrite formation. Neuron 2002;34:985-98.

6 Hinnen P, Eskens FA. Vascular disrupting agents in clinical development. Br J Cancer 2007;96:1159-65.

7 Lawrence NJ, Patterson RP, Ooi LL, Cook D, Ducki S. Effects of alpha-substitutions on structure and biological activity of anticancer chalcones. Bioorg Med Chem Lett 2006;16:5844-8.

8 Nobre-Junior HV, Oliveira RA, Maia FD, Nogueira MA, de Moraes MO, Bandeira MA, Andrade GM, Viana GS. Neuroprotective effects of chalcones from Myracrodruon urundeuva on 6-hydroxydopamine-induced cytotoxicity in rat mesencephalic cells. Neurochem Res 2009;34:1066-75.

9 Takano K, Kitao Y, Tabata Y, Miura H, Sato K, Takuma K, Yamada K, Hibino S, Choshi T, Iinuma M, Suzuki H, Murakami R, Yamada M, Ogawa S, Hori O. A dibenzoylmethane derivative protects dopaminergic neurons against both oxidative stress and endoplasmic reticulum stress. Am J Physiol Cell Physiol 2007;293:C1884-94.

10 Hadfield JA, Ducki S, Hirst N, McGown AT. Tubulin and microtubules as targets for anticancer drugs. Prog Cell Cycle Res 2003;5:309-25.

11 Kuhnle M, Egger M, Muller C, Mahringer A, Bernhardt G, Fricker G, Konig B, Buschauer A. Potent and selective inhibitors of breast cancer resistance protein (ABCG2) derived from the p-glycoprotein (ABCB1) modulator tariquidar. J Med Chem 2009;52:1190-7.

12 Huszti Z, Madarasz E. Histamine (HA) suppresses the production of tumor necrosis factor alpha (TNFalpha) in cultured astroglial cells. Inflamm Res 2002;51(Suppl 1):S6162. 
13 Schlett K, Herberth B, Madarasz E. In vitro pattern formation during neurogenesis in neuroectodermal progenitor cells immortalized by p53-deficiency. Int J Dev Neurosci 1997; 15:795-804.

14 Kornyei Z, Szlavik V, Szabo B, Gocza E, Czirok A, Madarasz E. Humoral and contact interactions in astroglia/stem cell co-cultures in the course of glia-induced neurogenesis. Glia 2005;49:430-44.

15 Mosmann T. Rapid colorimetric assay for cellular growth and survival: application to proliferation and cytotoxicity assays. J Immunol Methods 1983;65:55-63.

16 Kohno K, Kikuchi J, Sato S, Takano H, Saburi Y, Asoh K, Kuwano M. Vincristineresistant human cancer $\mathrm{KB}$ cell line and increased expression of multidrug-resistance gene. Jpn J Cancer Res 1988;79:1238-46.

17 Krishan A. Rapid flow cytofluorometric analysis of mammalian cell cycle by propidium iodide staining. J Cell Biol 1975;66:188-93.

18 Reynolds ES. The use of lead citrate at high $\mathrm{pH}$ as an electron-opaque stain in electron microscopy. The Journal of cell biology 1963;17:208-12.

19 Jordan MA, Wilson L. Microtubules as a target for anticancer drugs. Nat Rev Cancer 2004;4:253-65.

20 Schlett K, Madarasz E. Retinoic acid induced neural differentiation in a neuroectodermal cell line immortalized by p53 deficiency. J Neurosci Res 1997;47:405-15.

21 Kok JW, Veldman RJ, Klappe K, Koning H, Filipeanu CM, Muller M. Differential expression of sphingolipids in MRP1 overexpressing HT29 cells. Int J Cancer 2000;87:172-8.

22 Punnonen EL, Ryhanen K, Marjomaki VS. At reduced temperature, endocytic membrane traffic is blocked in multivesicular carrier endosomes in rat cardiac myocytes. Eur J Cell Biol 1998;75:344-52.

23 Stirling L, Williams MR, Morielli AD. Dual roles for RHOA/RHO-kinase in the regulated trafficking of a voltage-sensitive potassium channel. Mol Biol Cell 2009;20:2991-3002.

24 Kapp T, Muller S, Gust R. Dinuclear alkylamine platinum(II) complexes of [1,2-bis(4fluorophenyl)ethylenediamine]platinum(II): influence of endocytosis and copper and organic cation transport systems on cellular uptake. ChemMedChem 2006;1:560-4. 
25 Ishida S, Lee J, Thiele DJ, Herskowitz I. Uptake of the anticancer drug cisplatin mediated by the copper transporter Ctr1 in yeast and mammals. Proc Natl Acad Sci U S A 2002;99:14298-302.

26 Ivanov AI, Nusrat A, Parkos CA. Endocytosis of epithelial apical junctional proteins by a clathrin-mediated pathway into a unique storage compartment. Mol Biol Cell 2004;15:176-88.

27 Meier O, Boucke K, Hammer SV, Keller S, Stidwill RP, Hemmi S, Greber UF. Adenovirus triggers macropinocytosis and endosomal leakage together with its clathrinmediated uptake. J Cell Biol 2002;158:1119-31.

28 Zhang J, Li Y, Shen B. PI3-K/Akt pathway contributes to IL-6-dependent growth of 7TD1 cells. Cancer Cell Int 2003;3:1-4.

29 Nawa M, Takasaki T, Yamada K, Kurane I, Akatsuka T. Interference in Japanese encephalitis virus infection of Vero cells by a cationic amphiphilic drug, chlorpromazine. J Gen Virol 2003;84:1737-41.

30 Koepsell H, Lips K, Volk C. Polyspecific organic cation transporters: structure, function, physiological roles, and biopharmaceutical implications. Pharm Res 2007;24:1227-51.

31 Simstein R, Burow M, Parker A, Weldon C, Beckman B. Apoptosis, chemoresistance, and breast cancer: insights from the MCF-7 cell model system. Exp Biol Med 2003;228:995-1003.

32 Smith BJ, Doran AC, McLean S, Tingley FD, O'Neill BT, Kajiji SM. P-glycoprotein efflux at the blood-brain barrier mediates differences in brain disposition and pharmacodynamics between two structurally related neurokinin-1 receptor antagonists. $\mathbf{J}$ Pharmacol Exp Ther 2001;298:1252-9.

33 Hyde SC, Emsley P, Hartshorn MJ, Mimmack MM, Gileadi U, Pearce SR, Gallagher M P, Gill DR, Hubbard RE, Higgins CF. Structural model of ATP-binding proteins associated with cystic fibrosis, multidrug resistance and bacterial transport. Nature 1990;346:362-65.

34 Borst P, Kool M, Evers R. Do cMOAT (MRP2), other MRP homologues, and LRP play a role in MDR? Semin Cancer Biol 1997;8:205-13.

35 Schwab D, Fischer H, Tabatabaei A, Poli S, Huwyler J. Comparison of in vitro Pglycoprotein screening assays: recommendations for their use in drug discovery. $\mathrm{J}$ Med Chem 2003;46:1716-25. 
36 Sharom FJ. The P-glycoprotein efflux pump: how does it transport drugs? J Membr Biol 1997;160:161-75.

37 Marchan R, Hammond CL, Ballatori N. Multidrug resistance-associated protein 1 as a major mediator of basal and apoptotic glutathione release. Biochim Biophys Acta 2008;1778:2413-20.

38 Oku N, Saito N, Okada S, Watanabe N, Kobayashi Y. Permeability change of liposomal membrane induced by interleukin-1 alpha. J Biochem 1995;118:832-35.

39 Robey RW, Honjo Y, van de Laar A, Miyake K, Regis JT, Litman T, Bates SE. A functional assay for detection of the mitoxantrone resistance protein, MXR (ABCG2). Biochim Biophys Acta 2001;1512:171-82.

40 Hasaka TP, Myers KA, Baas PW. Role of actin filaments in the axonal transport of microtubules. J Neurosci 2004;24:11291-301.

41 Hegedus B, Czirok A, Fazekas I, B'Abel T, Madarasz E, Vicsek T. Locomotion and proliferation of glioblastoma cells in vitro: statistical evaluation of videomicroscopic observations. J Neurosurg 2000;92:428-34.

42 Wang D, Lippard SJ. Cellular processing of platinum anticancer drugs. Nat Rev Drug Discov 2005;4:307-20.

43 Shen KH, Chang JK, Hsu YL, Kuo PL. Chalcone arrests cell cycle progression and induces apoptosis through induction of mitochondrial pathway and inhibition of nuclear factor kappa B signalling in human bladder cancer cells. Basic Clin Pharmacol Toxicol 2007;101:254-61.

44 Vitale I, Antoccia A, Cenciarelli C, Crateri P, Meschini S, Arancia G, Pisano C, Tanzarella C. Combretastatin CA-4 and combretastatin derivative induce mitotic catastrophe dependent on spindle checkpoint and caspase-3 activation in non-small cell lung cancer cells. Apoptosis 2007;12:155-66.

45 Chan DC. Mitochondrial fusion and fission in mammals. Annu Rev Cell Dev Biol 2006;22:79-99.

46 Zhang S, Lovejoy KS, Shima JE, Lagpacan LL, Shu Y, Lapuk A, Chen Y, Komori T, Gray JW, Chen X, Lippard SJ, Giacomini KM. Organic cation transporters are determinants of oxaliplatin cytotoxicity. Cancer Res 2006;66:8847-57.

47 Castedo M, Perfettini JL, Roumier T, Andreau K, Medema R, Kroemer G. Cell death by mitotic catastrophe: a molecular definition. Oncogene 2004;23:2825-37. 
48 Mukherjee S, Chiu R, Leung SM, Shields D. Fragmentation of the Golgi apparatus: an early apoptotic event independent of the cytoskeleton. Traffic 2007;8:369-78. 
((Figure 1))<smiles></smiles>

Fig. 1. Chalcone 1 and its dichlorido(6-aminomethylnicotinate)Pt(II) complex 2.

\section{((Figure 2))}

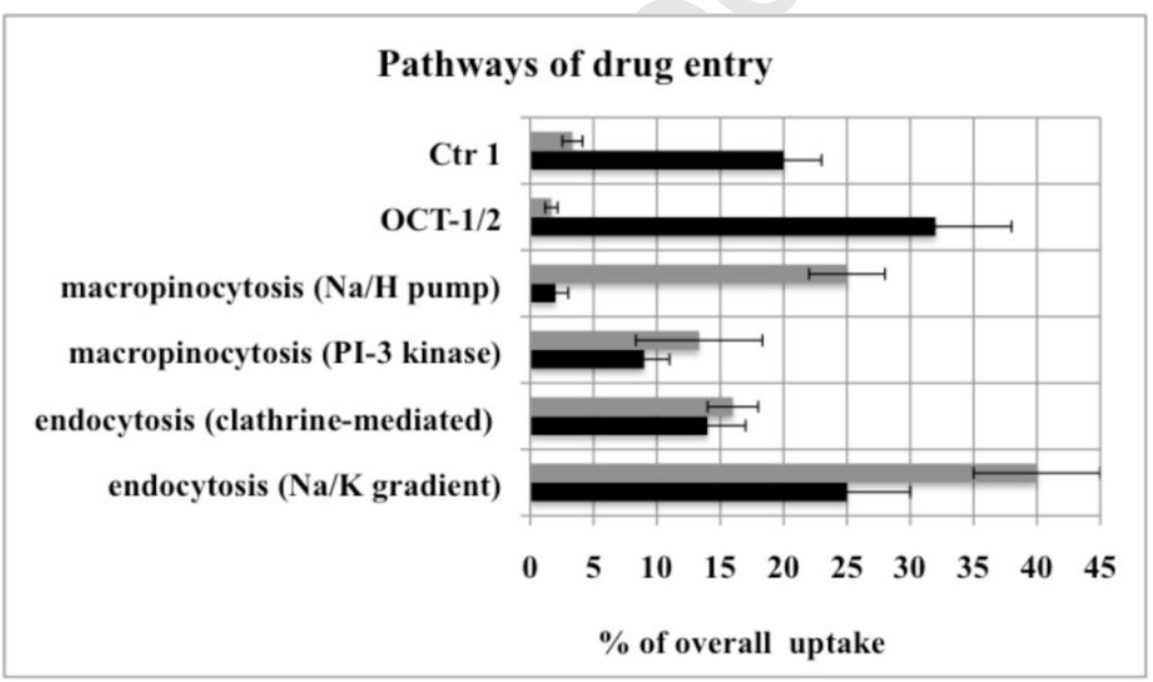

Fig. 2. Contribution of various pathways to the accumulation of chalcone $\mathbf{1}$ (grey bars) and its platinum complex 2 (black bars) by 518A2 melanoma cells as calculated from the attenuation of their cytotoxicity upon addition of specific inhibitors. 


\section{((Figure 3))}

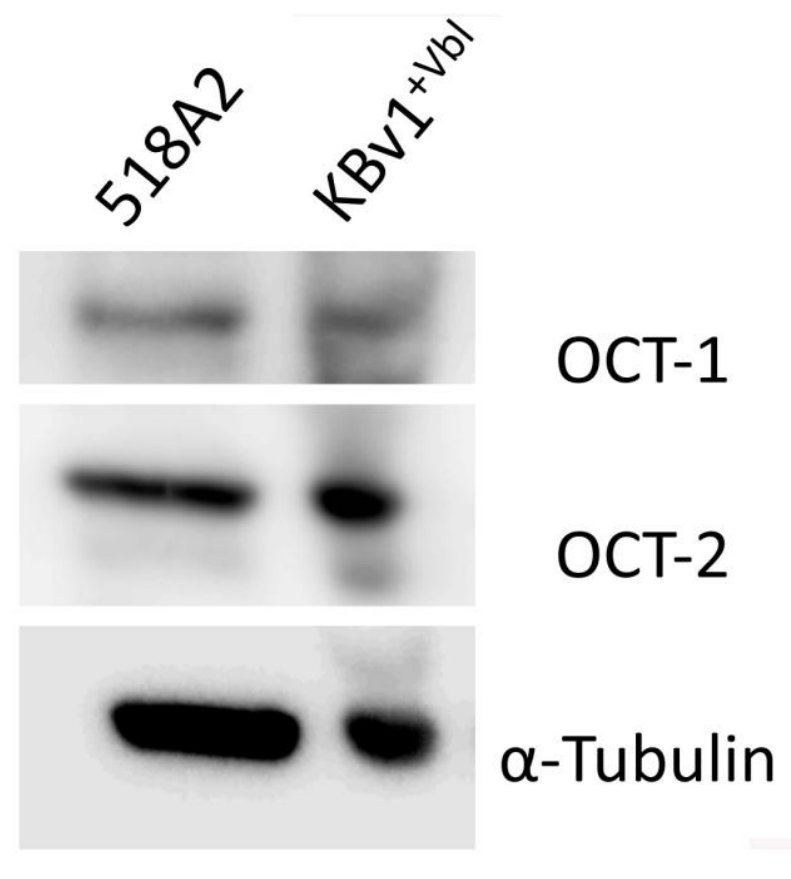

Fig. 3. Semiquantitative westernblot analysis for organic cation transporters OCT-1 ( 56 $\mathrm{kDa})$ and OCT-2 $(\sim 30 \mathrm{kDa})$ in 518A2 melanoma and $\mathrm{KBv} 1^{+\mathrm{Vbl}}$ cervix carcinoma cells. Samples were probed with an antibody against $\alpha$-tubulin $(60 \mathrm{kDa})$ to show equal loading of lanes. 


\section{((Figure 4))}
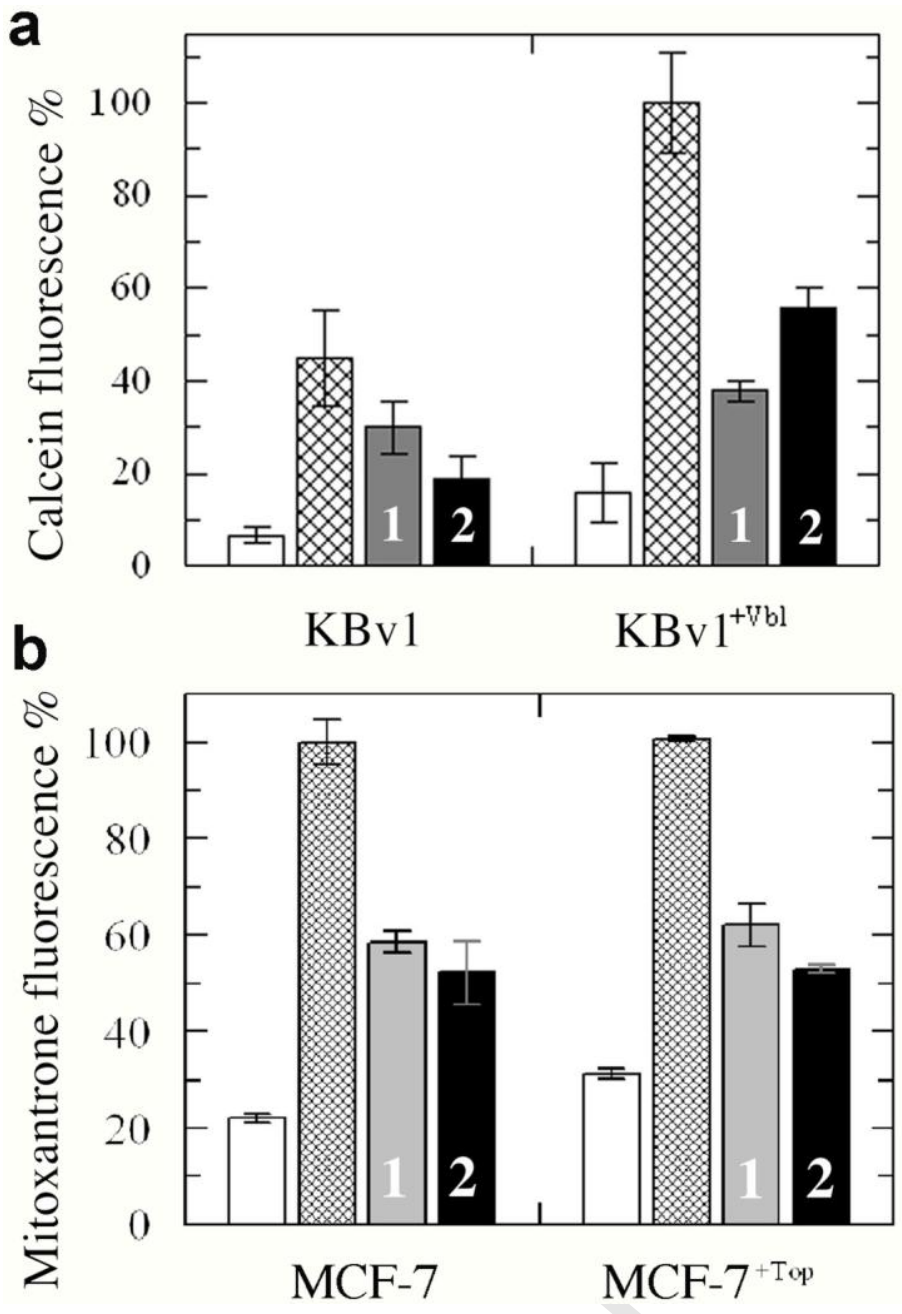

Fig. 4. a: calcein-AM assay: \% inhibition of $\mathrm{P}$-gp drug transporters in $\mathrm{KBv} 1$ and $\mathrm{KBv} 1^{+\mathrm{Vbl}}$ cells by $50 \mu \mathrm{M}$ each of chalcone 1 (grey bar) and Pt-complex 2 (black bar) relative to the inhibition of cells by verapamil (hatched bar) after $15 \mathrm{~min}$ exposure. White bar: negative control. Statistical paired t-test showed differences of data pairs to be significantly greater than zero (negative control: $\mathrm{p}=1.0617 \times 10^{-4}$; positive control verapamil: $\mathrm{p}=0.0038 \times 10^{-4}$; chalcone 1: $p=45.58 \times 10^{-4}$; complex $2: p=7.02 \times 10^{-4}$ ). A $95 \%$ confidential interval confirms the significance of the observed measurement differences.

b: mitoxantrone assay: \% inhibition of BCRP drug transporters in MCF-7 and MCF-7 $7^{+\mathrm{Top}}$ cells by $10 \mu \mathrm{M}$ each of chalcone 1 (grey bar) and Pt-complex 2 (black bar) relative to fumitremorgine $\mathrm{C}$ (hatched bar) after $30 \mathrm{~min}$ exposure. White bar: self-fluorescence of cells with added mitoxantrone (negative control). 


\section{((Figure 5))}

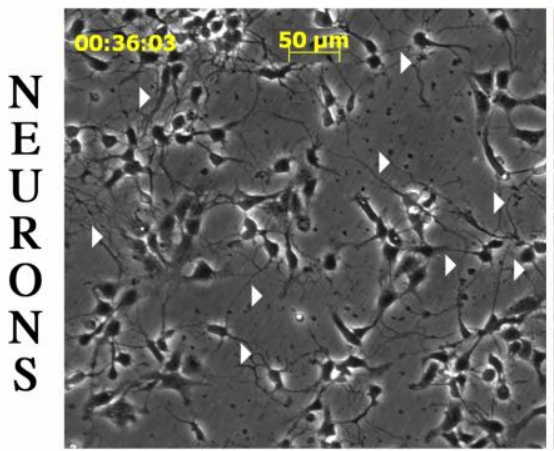

CONTROL

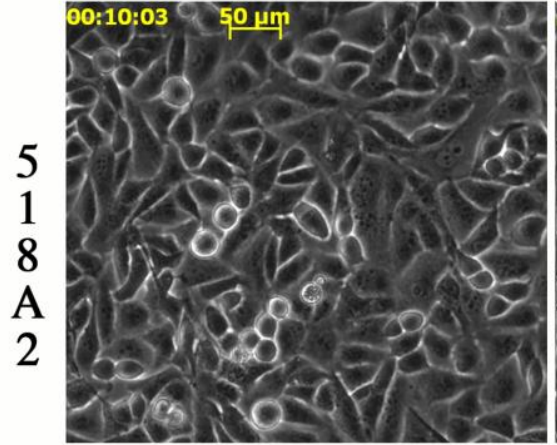

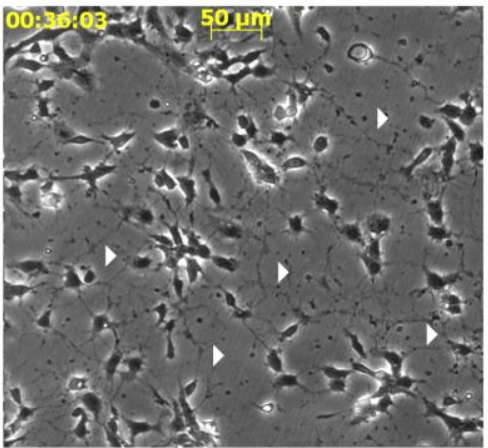

1

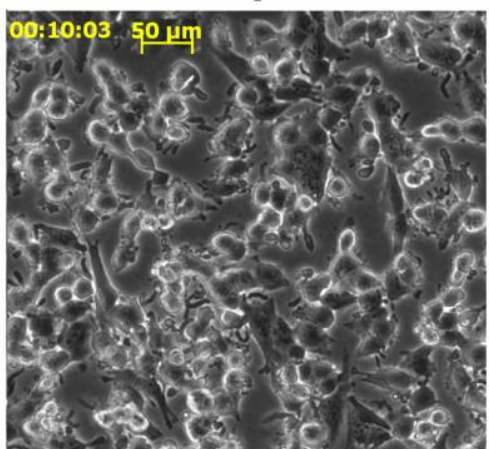

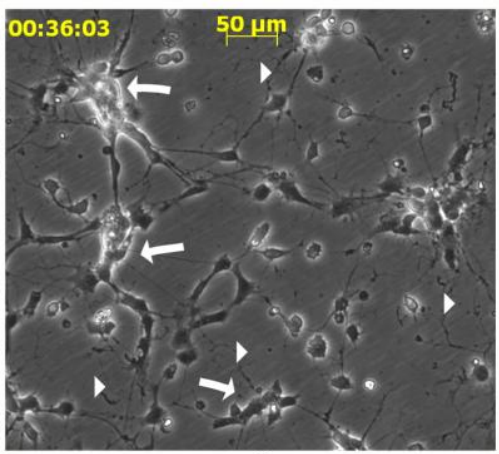

2

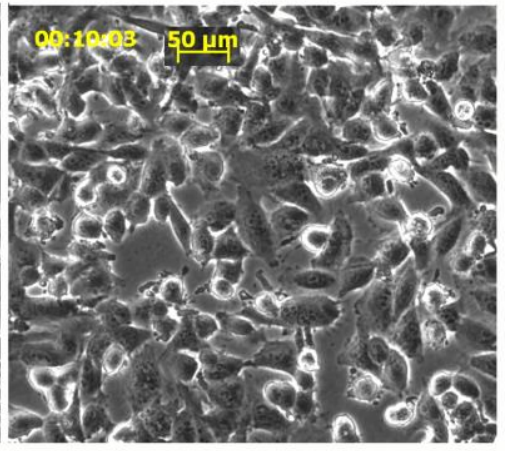

Fig. 5. Top row: left: untreated neurons with prolonged axons (arrowheads); middle: retraction of axons back to soma or decay (arrowheads) upon treatment with $10 \mu \mathrm{M} \mathrm{1}$; right: upon incubation with $10 \mu \mathrm{M} 2$ some axons (arrowheads) retracted and most somas coagulated (arrows). Bottom row: left: untreated 518A2 melanoma cells (control); middle: rounded cells of increased motility starting to detach after $10 \mathrm{~min}$ incubation with $10 \mu \mathrm{M}$ of 1 ; right: same effects delayed by 2 min upon treatment with $10 \mu \mathrm{M}$ of complex 2 . 


\section{((Figure 6))}
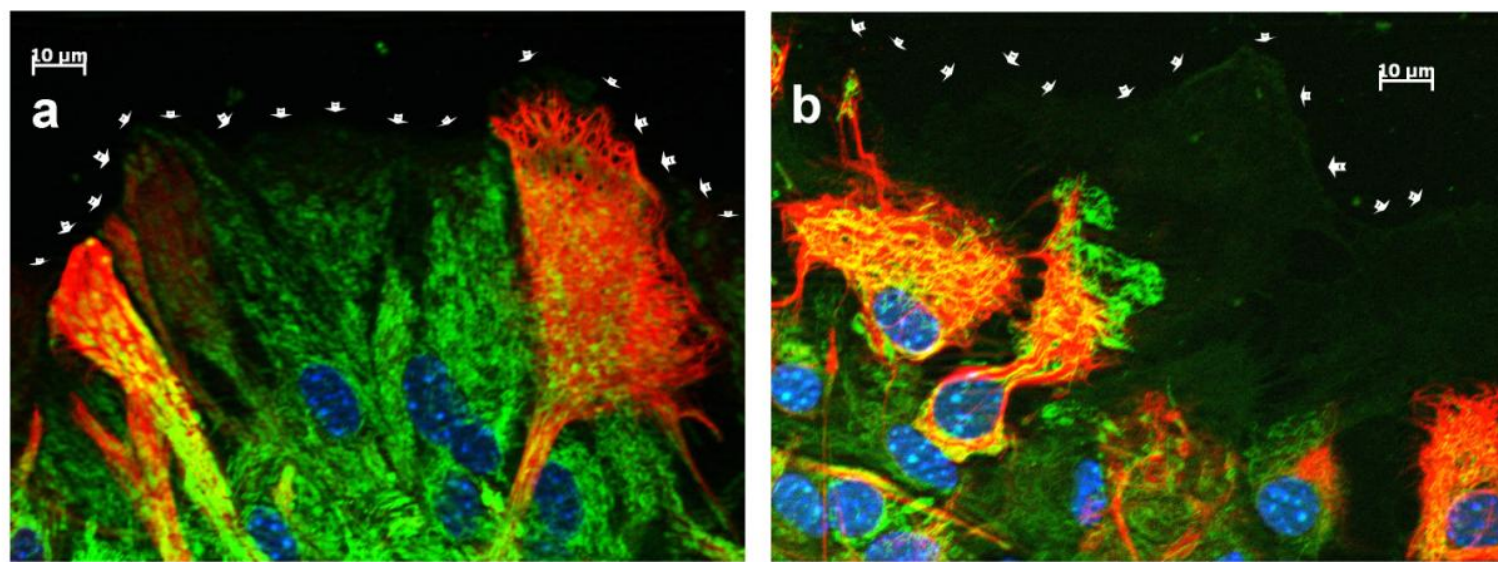

Fig. 6. Immunostaining of astroglia cells untreated (a) and treated with $10 \mu \mathrm{M}$ chalcone $\mathbf{1}$ for 72 h (b). Blue: nuclei stained with DAPI (4',6-diamidino-2-phenylindole); green: actin cytoskeleton stained with phalloidin; red: glial fibrillary acidic proteins (GFAP). White arrowheads indicate the edge of cell membranes. The pictures were taken with a fluorescence microscope (Zeiss Axiovert 200M) with a 63-fold oil immersion objective and the scanning module at $1024 \times 1024$ pixel resolution. 
((Figure 7))
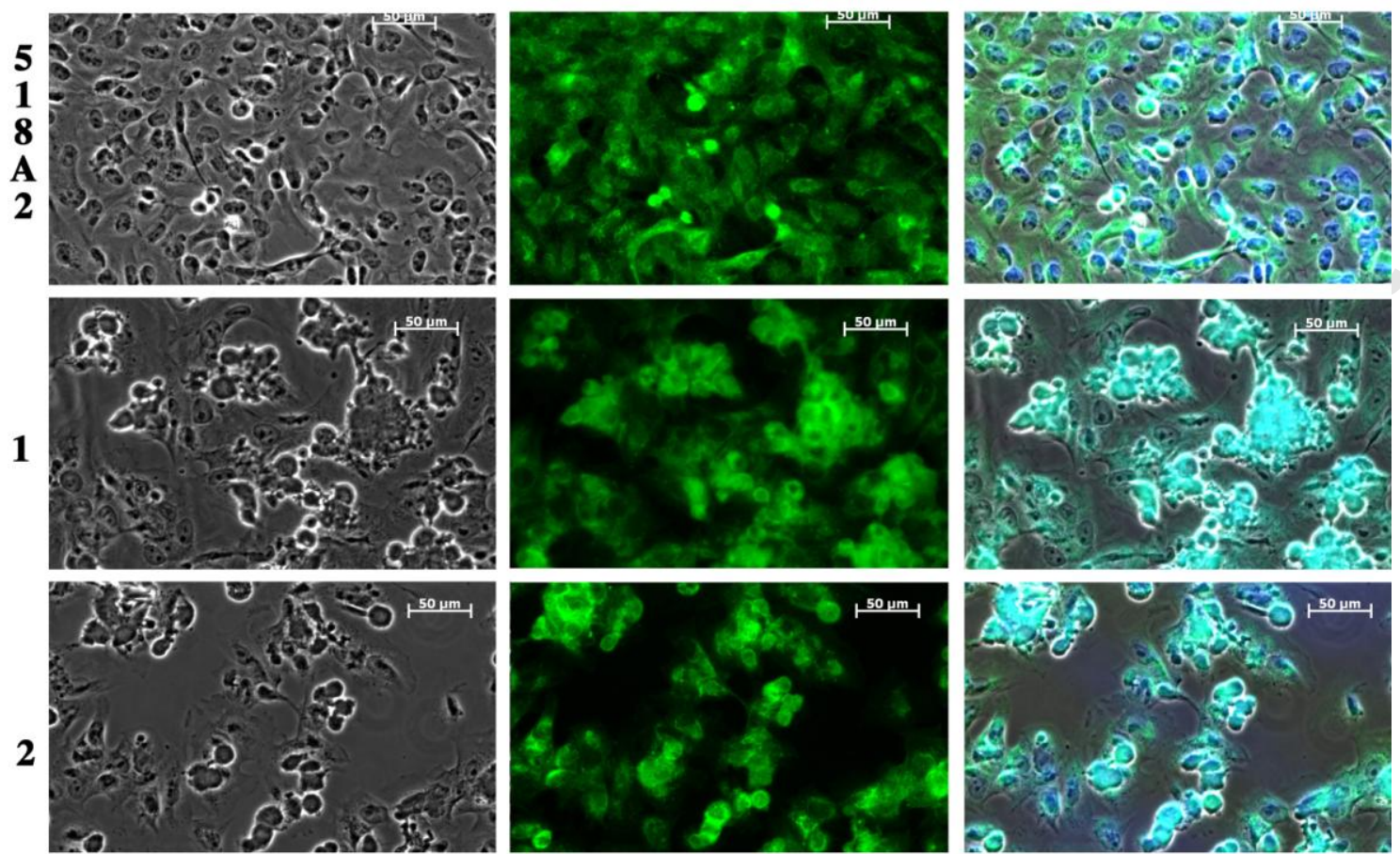

PHASE

ACTIN
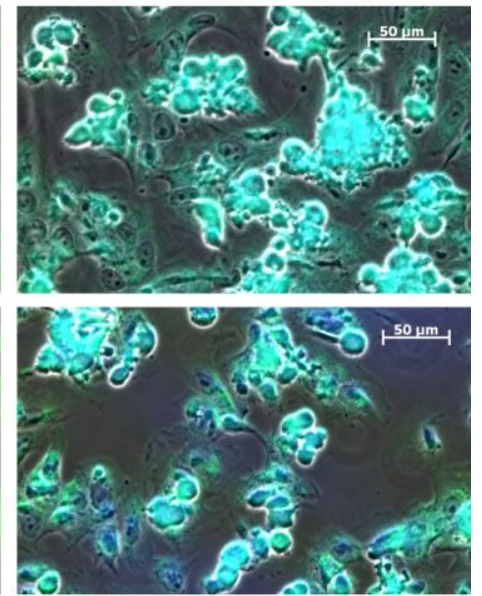

MERGE

Fig. 7. Immunostaining for actin of 518A2 cells untreated (top row), after $24 \mathrm{~h}$ incubation with $10 \mu \mathrm{M}$ chalcone 1 (middle row), and with $10 \mu \mathrm{M}$ Pt-complex 2 (bottom row). 
((Figure 8))

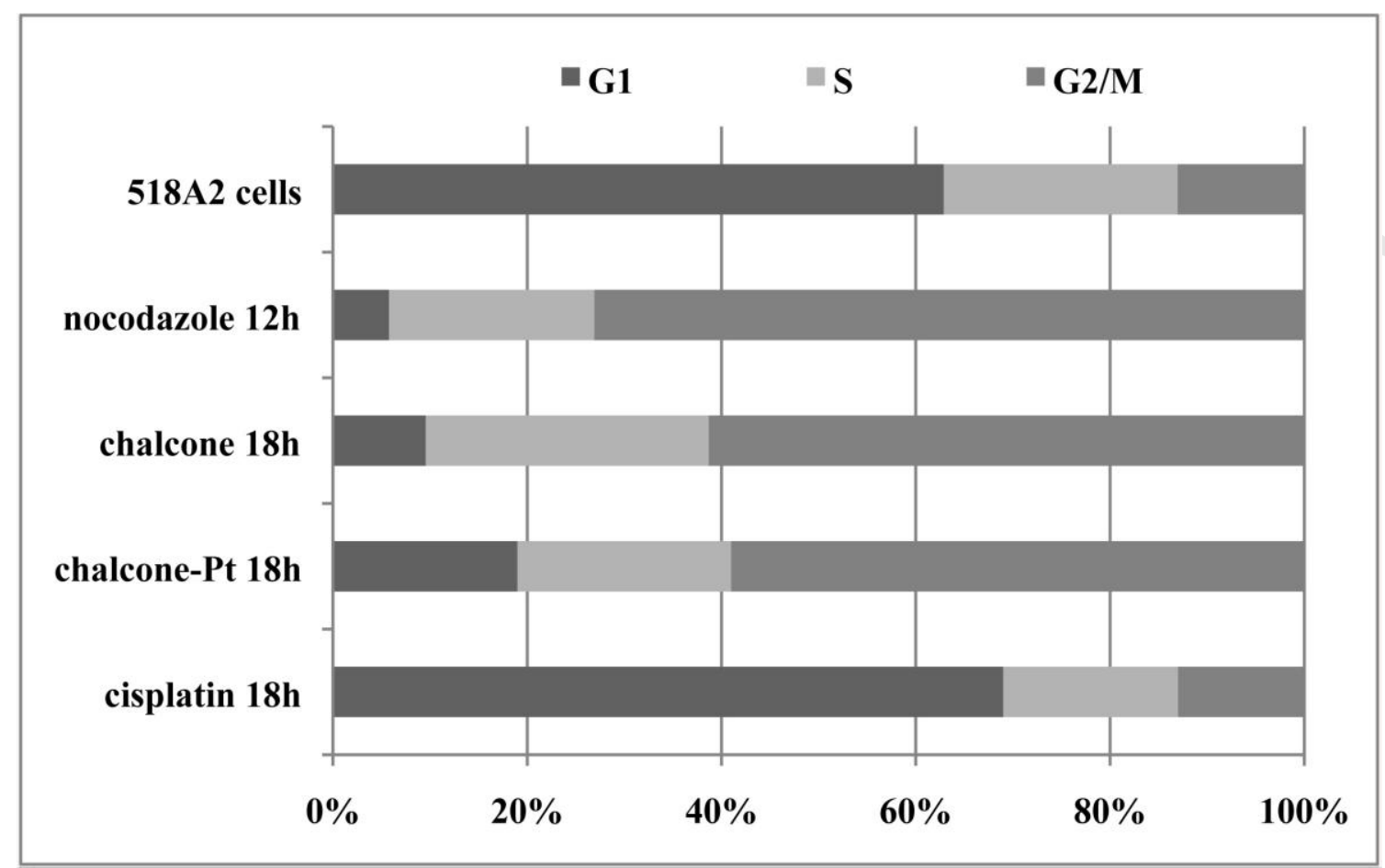

Fig. 8. Flow cytometric analysis of 518A2 melanoma cells stained with propidium iodide. The cells were treated with $250 \mu \mathrm{g} / \mathrm{mL}$ nocodazole or with $10 \mu \mathrm{M}$ of chalcone 1 , or chalconePt 2 or cisplatin. Detailed FACS profiles are available in the supplementary data file. 


\section{((Figure 9))}
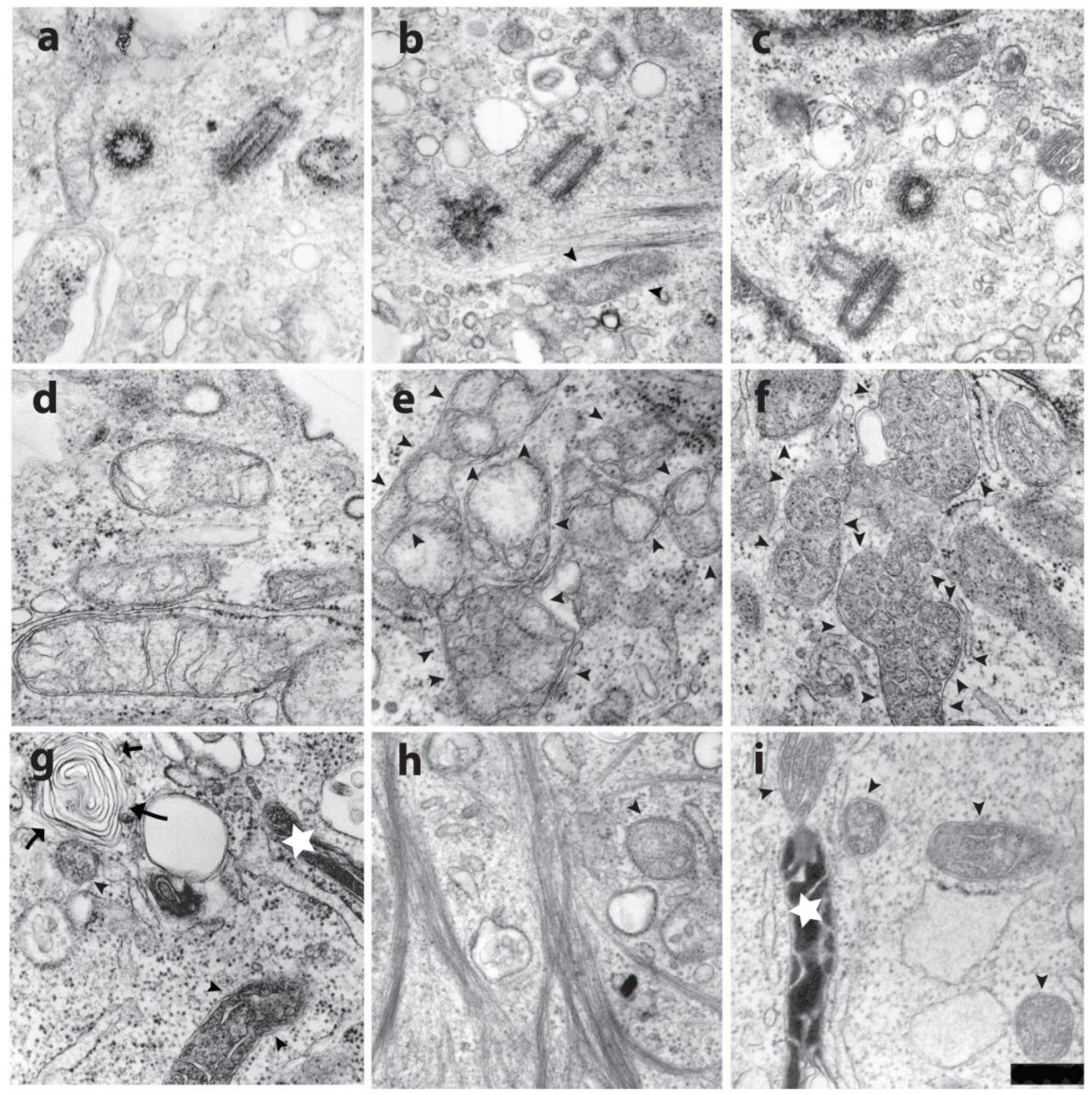

Fig. 9. TEM images of organelles in 518A2 cells. $a$, $d$ : untreated cells with image $a$ showing the cross and longitude section through the centrioles and image $d$ sound mitochondria with cristae invaginations surrounded by endoplasmic reticulum. $b, e, h$ : cells treated with 1. $c, f, g$, $i$ : cells treated with 2 . Image $e$ shows mitochondria at various stages of inner-membrane destruction, image $f$ the formation of multivesicular bodies (arrowheads). Some mitochondria were highly condensed ( $i, g$ stars) and some formed multi-lamellar bodies (arrows). Stress fibres are visible in panel $h$. Black bar indicates $0.4 \mu \mathrm{m}$. 
((Figure 10))
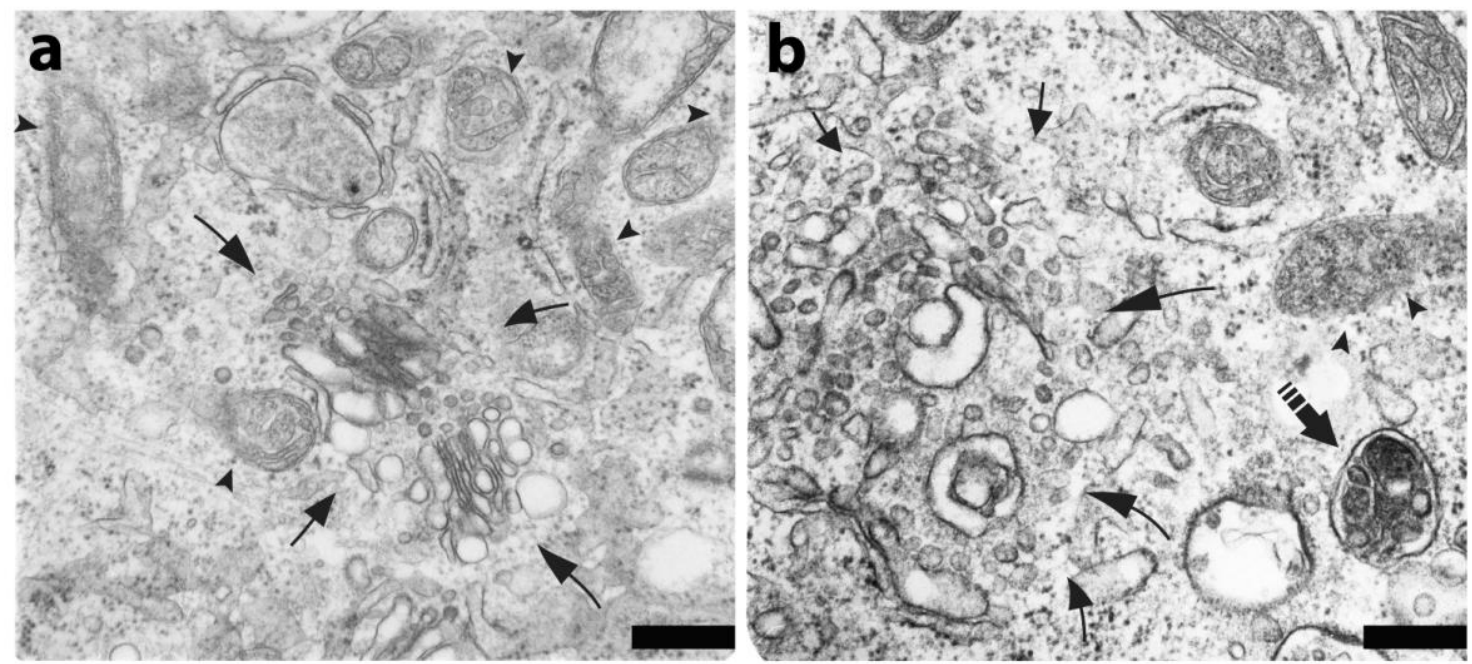

Fig. 10. TEM images of 518A2 cells treated with chalcone 1 (a) or complex 2 (b). Arrows indicate Golgi apparatuses, which are intact in (a) but fragmented in (b). Dashed arrow indicates an autophage. 
Table 1. Inhibitory concentrations $\mathrm{IC}_{50}{ }^{\mathrm{a}}$ in $\mu \mathrm{M}$ of chalcones $\mathbf{1}$ and $\mathbf{2}$ in various neural and non-neural cells (MTT-assay).

\begin{tabular}{|c|c|c|c|c|}
\hline $\begin{array}{l}\text { Compound/ } \\
\text { Cell line }\end{array}$ & $1(24 \mathrm{~h})$ & $\mathbf{1}(48 \mathrm{~h})$ & $\mathbf{2}(24 \mathrm{~h})$ & $\mathbf{2}(48 \mathrm{~h})$ \\
\hline Astroglia & 55 & $33 \pm 3$ & 100 & $100 \pm 4$ \\
\hline U87 & $45 \pm 5$ & $0.6 \pm 0.3$ & 55 & $0.14 \pm 0.08$ \\
\hline Neurons & $38 \pm 6$ & $1.3 \pm 0.1$ & $60 \pm 8$ & $1.5 \pm 0.3$ \\
\hline NE-4C & $2.8 \pm 0.6$ & $0.024 \pm 0.001$ & $2.4 \pm 0.7$ & $0.04 \pm 0.02$ \\
\hline C6 & $0.5 \pm 0.08$ & $0.15 \pm 0.02$ & $0.38 \pm 0.02$ & $0.17 \pm 0.02$ \\
\hline WEHI 164 & $11 \pm 1$ & $15 \pm 3$ & $9 \pm 1$ & $24 \pm 4$ \\
\hline $518 \mathrm{~A} 2$ & $11.5 \pm 0.6$ & $1.0 \pm 0.4$ & $21 \pm 0.7$ & $3.4 \pm 0.9$ \\
\hline MCF-7 & $10.7 \pm 1.3$ & $13.4 \pm 1.1$ & $40 \pm 2$ & $28 \pm 4$ \\
\hline $\mathrm{MCF}-7^{+\mathrm{Top}}$ & $12.5 \pm 3.1$ & $1.6 \pm 0.1$ & $34.6 \pm 3.6$ & $18 \pm 1.2$ \\
\hline KBv1 & $1.6 \pm 0.1$ & $0.7 \pm 0.05$ & $0.8 \pm 0.09$ & $0.5 \pm 0.03$ \\
\hline $\mathrm{KBv} 1^{+\mathrm{Vbl}}$ & $2.0 \pm 0.3$ & $0.2 \pm 0.04$ & $1.2 \pm 0.3$ & $0.12 \pm 0.02$ \\
\hline HT-29 & $43 \pm 3$ & $37 \pm 1$ & $76 \pm 4$ & $38 \pm 6$ \\
\hline HT $-29^{+ \text {Colc }}$ & $37 \pm 6$ & $24 \pm 6$ & $47 \pm 1$ & $24 \pm 0.7$ \\
\hline
\end{tabular}

${ }^{a}$ Values are derived from concentration-response curves obtained by measuring the percentual absorbance of vital cells relative to untreated controls (100\%) after 24 and $48 \mathrm{~h}$ exposure of selected cells to test compounds in the MTT assay. Values represent means of at least three independent experiments \pm standard deviation. 
((Captions to Figures:))

Fig. 1. Chalcone 1 and its dichlorido(6-aminomethylnicotinate)Pt(II) complex 2.

Fig. 2. Contribution of various pathways to the accumulation of chalcone $\mathbf{1}$ (grey bars) and its platinum complex 2 (black bars) by 518A2 melanoma cells as calculated from the attenuation of their cytotoxicity upon addition of specific inhibitors.

Fig. 3. Semiquantitative westernblot analysis for organic cation transporters OCT-1 ( 56 $\mathrm{kDa})$ and OCT-2 $(\sim 30 \mathrm{kDa})$ in 518A2 melanoma and $\mathrm{KBv}^{+\mathrm{Vbl}}$ cervix carcinoma cells. Samples were probed with an antibody against $\alpha$-tubulin $(60 \mathrm{kDa})$ to show equal loading of lanes.

Fig. 4. a: calcein-AM assay: \% inhibition of $\mathrm{P}$-gp drug transporters in $\mathrm{KBv} 1$ and $\mathrm{KBv1}^{+\mathrm{Vbl}}$ cells by $50 \mu \mathrm{M}$ each of chalcone 1 (grey bar) and Pt-complex 2 (black bar) relative to the inhibition of cells by verapamil (hatched bar) after $15 \mathrm{~min}$ exposure. White bar: negative control. Statistical paired t-test showed differences of data pairs to be significantly greater than zero (negative control: $\mathrm{p}=1.0617 \times 10^{-4}$; positive control verapamil: $\mathrm{p}=0.0038 \times 10^{-4}$; chalcone 1: $p=45.58 \times 10^{-4}$; complex $2: p=7.02 \times 10^{-4}$ ). A $95 \%$ confidential interval confirms the significance of the observed measurement differences. b: mitoxantrone assay: \% inhibition of BCRP drug transporters in MCF-7 and MCF- $7^{+ \text {Top }}$ cells by $10 \mu \mathrm{M}$ each of chalcone 1 (grey bar) and Pt-complex 2 (black bar) relative to fumitremorgine $\mathrm{C}$ (hatched bar) after $30 \mathrm{~min}$ exposure. White bar: self-fluorescence of cells with added mitoxantrone (negative control).

Fig. 5. Top row: left: untreated neurons with prolonged axons (arrowheads); middle: retraction of axons back to soma or decay (arrowheads) upon treatment with $10 \mu \mathrm{M} \mathrm{1}$; right: upon incubation with $10 \mu \mathrm{M} 2$ some axons (arrowheads) retracted and most somas coagulated (arrows). Bottom row: left: untreated 518A2 melanoma cells (control); middle: rounded cells of increased motility starting to detach after $10 \mathrm{~min}$ incubation with $10 \mu \mathrm{M}$ of 1 ; right: same effects delayed by 2 min upon treatment with $10 \mu \mathrm{M}$ of complex 2 .

Fig. 6. Immunostaining of astroglia cells untreated (a) and treated with $10 \mu \mathrm{M}$ chalcone $\mathbf{1}$ for 72 h (b). Blue: nuclei stained with DAPI (4',6-diamidino-2-phenylindole); green: actin cytoskeleton stained with phalloidin; red: glial fibrillary acidic proteins (GFAP). White arrowheads indicate the edge of cell membranes. The pictures were taken with a fluorescence 
microscope (Zeiss Axiovert 200M) with a 63-fold oil immersion objective and the scanning module at 1024 x 1024 pixel resolution.

Fig. 7. Immunostaining for actin of 518A2 cells untreated (top row), after $24 \mathrm{~h}$ incubation with $10 \mu \mathrm{M}$ chalcone 1 (middle row), and with $10 \mu \mathrm{M}$ Pt-complex 2 (bottom row).

Fig. 8. Flow cytometric analysis of 518A2 melanoma cells stained with propidium iodide. The cells were treated with $250 \mu \mathrm{g} / \mathrm{mL}$ nocodazole or with $10 \mu \mathrm{M}$ of chalcone 1 , or chalconePt 2 or cisplatin. Detailed FACS profiles are available in the supplementary data file.

Fig. 9. TEM images of organelles in 518A2 cells. $a$, $d$ : untreated cells with image $a$ showing the cross and longitude section through the centrioles and image $d$ sound mitochondria with cristae invaginations surrounded by endoplasmic reticulum. $b, e, h$ : cells treated with 1. $c, f, g$, $i$ : cells treated with 2 . Image $e$ shows mitochondria at various stages of inner-membrane destruction, image $f$ the formation of multivesicular bodies (arrowheads). Some mitochondria were highly condensed ( $i, g$ stars) and some formed multi-lamellar bodies (arrows). Stress fibres are visible in panel $h$. Black bar indicates $0.4 \mu \mathrm{m}$.

Fig. 10. TEM images of 518A2 cells treated with chalcone $\mathbf{1}$ (a) or complex 2 (b). Arrows indicate Golgi apparatuses, which are intact in (a) but fragmented in (b). Dashed arrow indicates an autophage. 


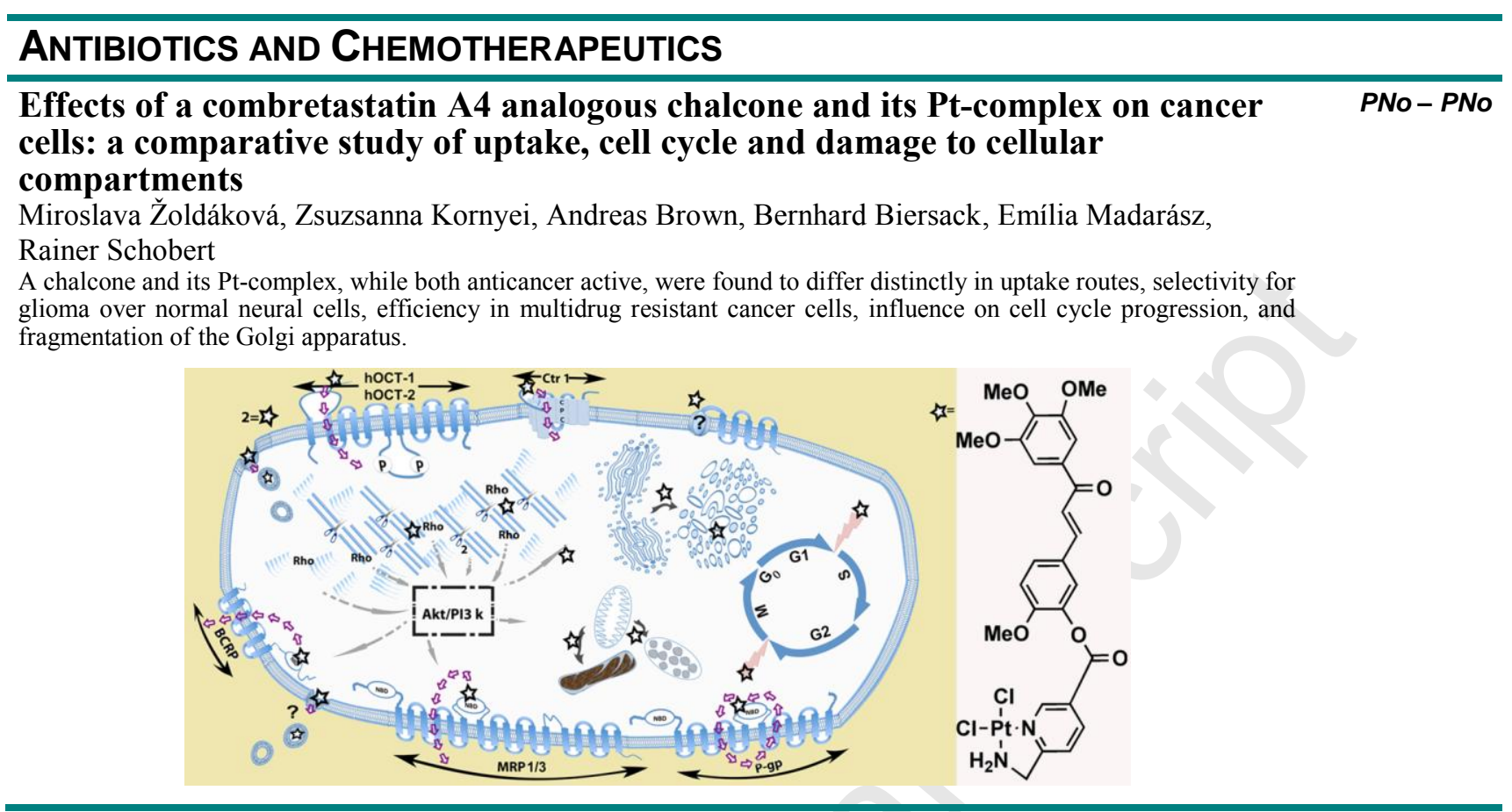




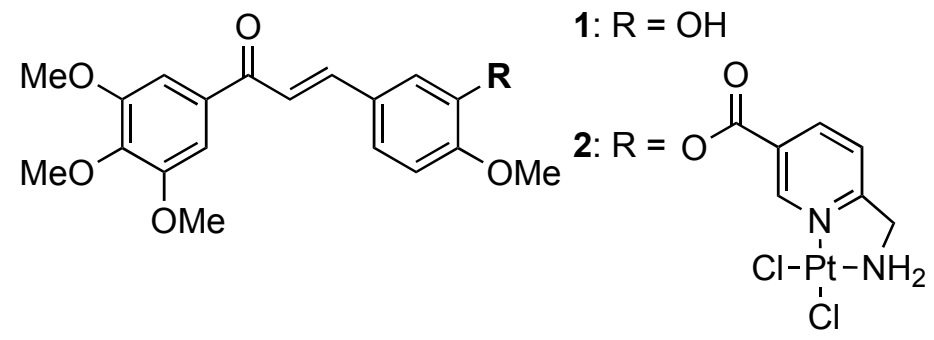




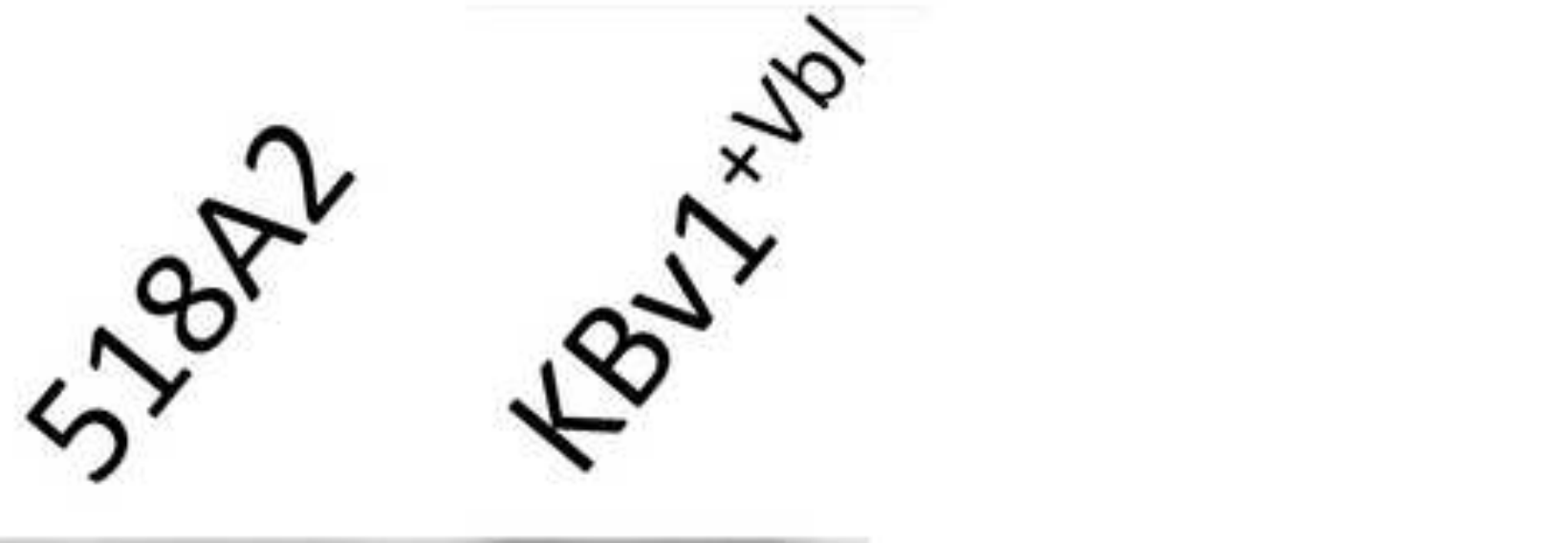

\section{OCT-1}

OCT-2

$\alpha-$ Tubulin Page 40 of 48
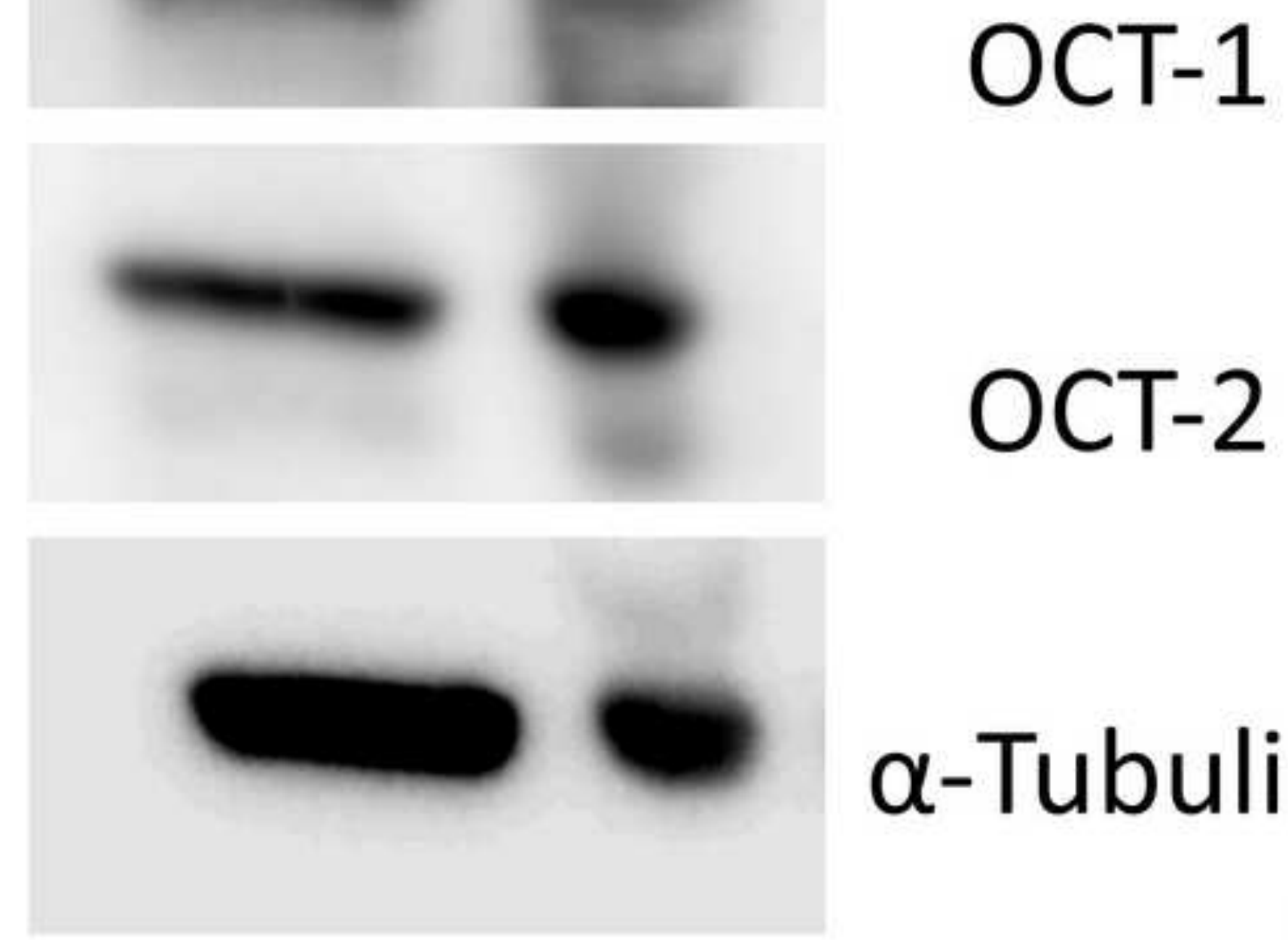
Page 40 of 48

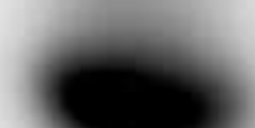
$=4$
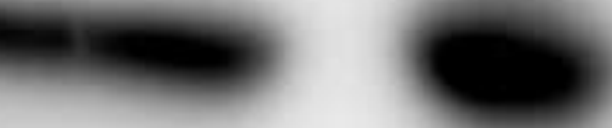
a

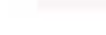


a

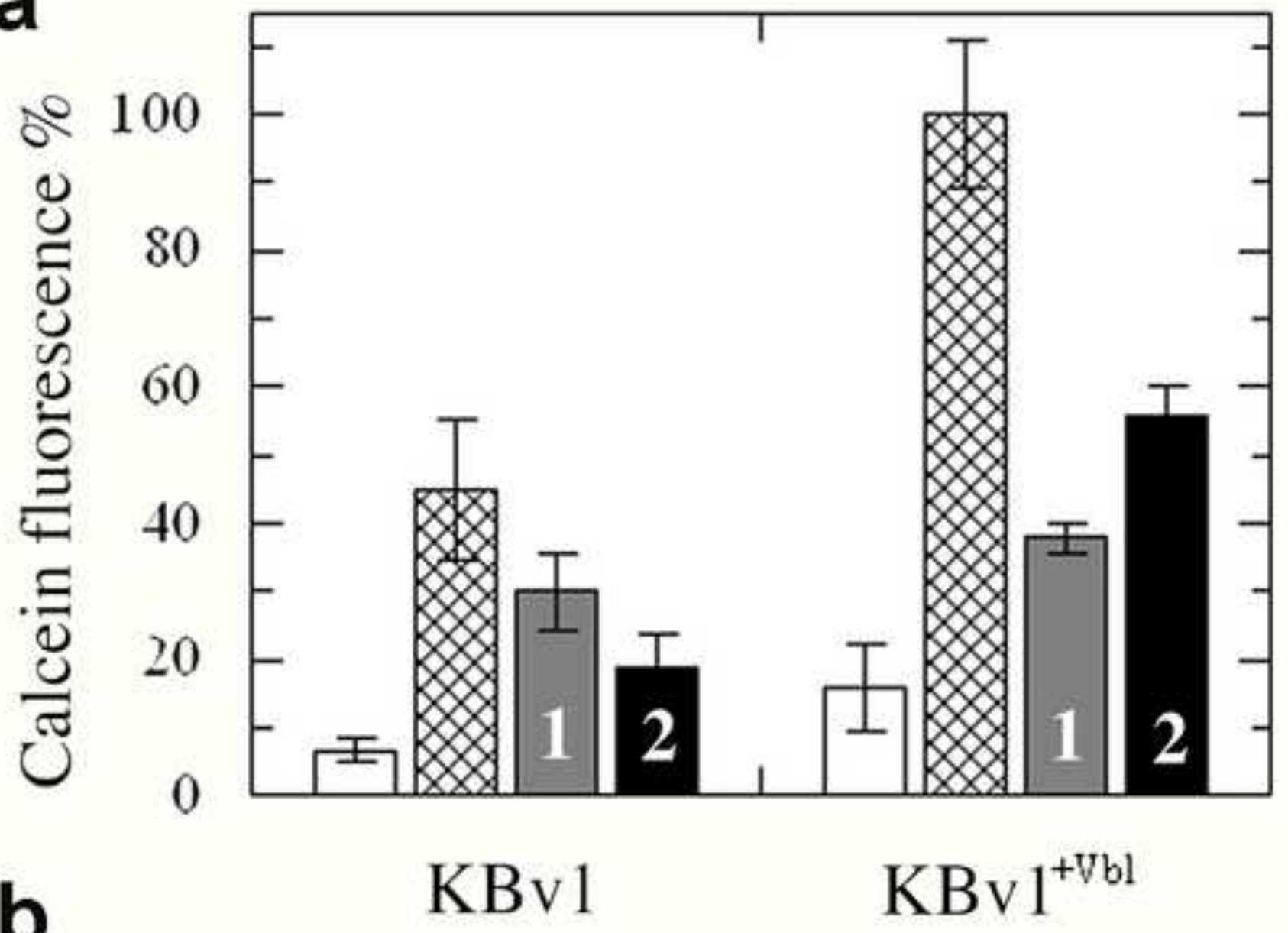

se

政

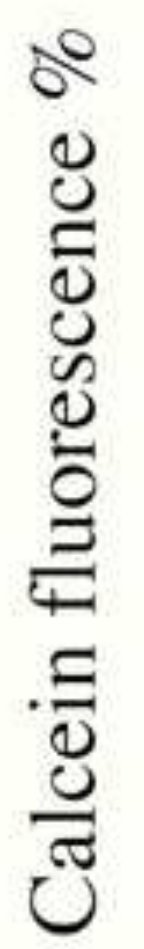

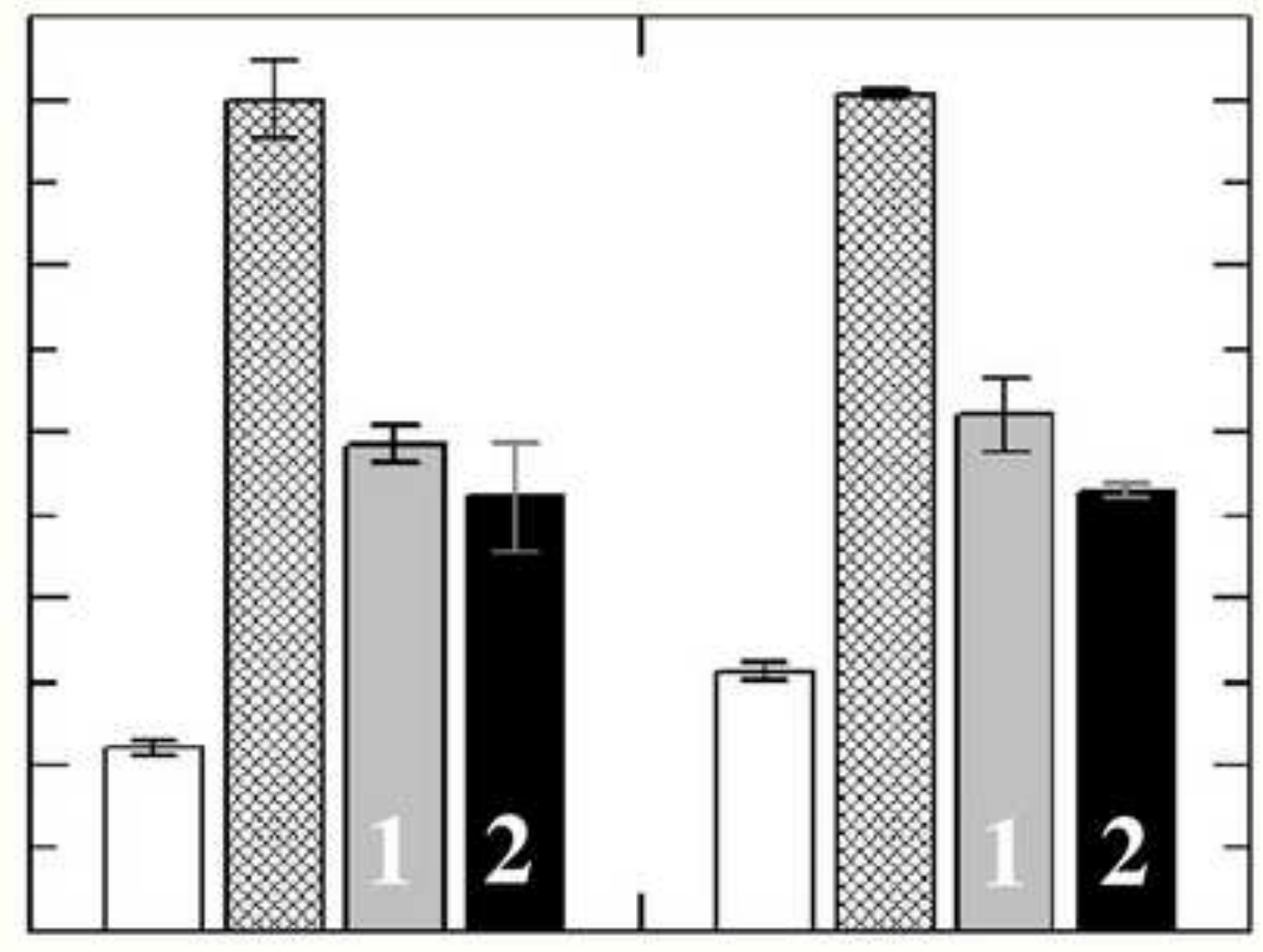

()

$$
\mathrm{MCF}-7 \quad \mathrm{MCF}-7^{+\mathrm{Top}}
$$


N
E
U
R
O
N
S

\section{CONTROL}

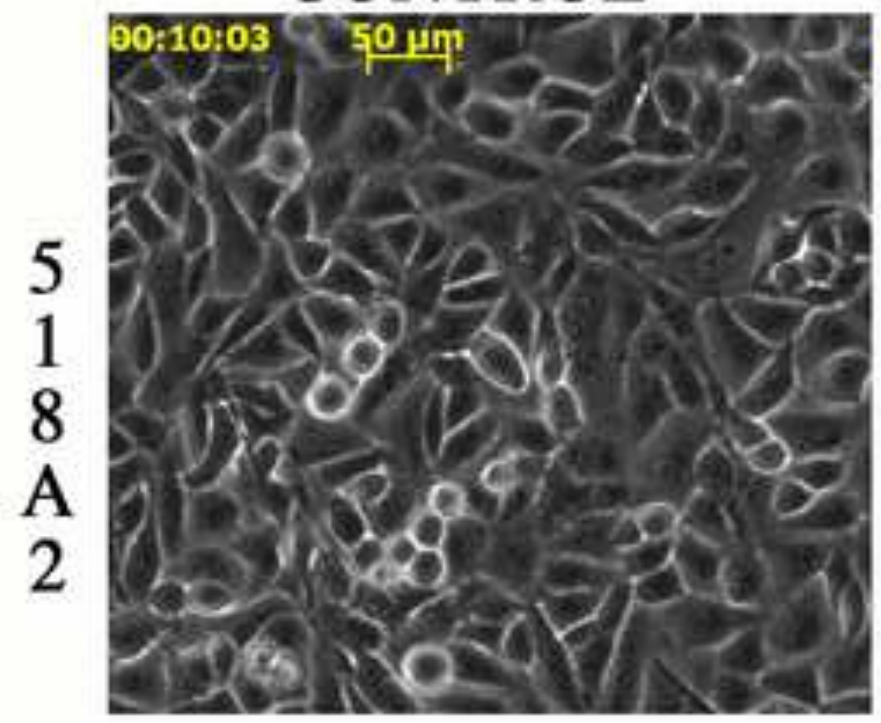

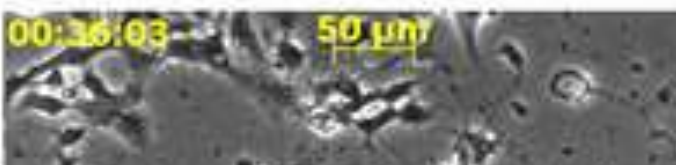

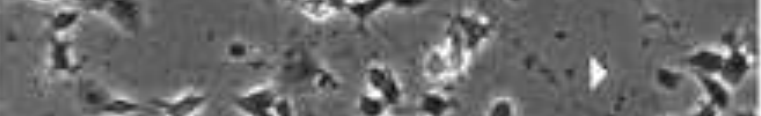

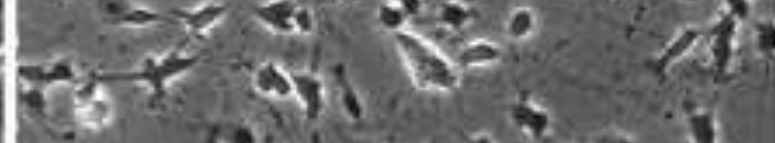

$2 x+5 x^{2}+x^{4}$

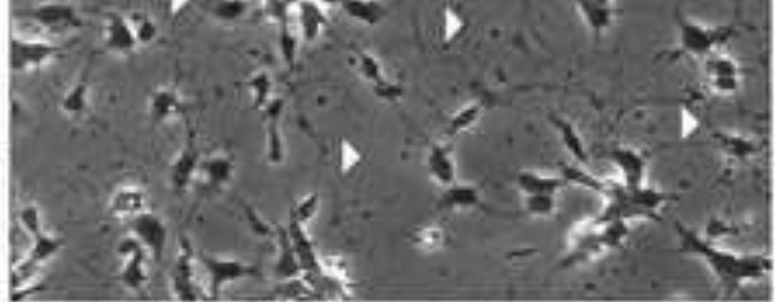

2. giverat 1

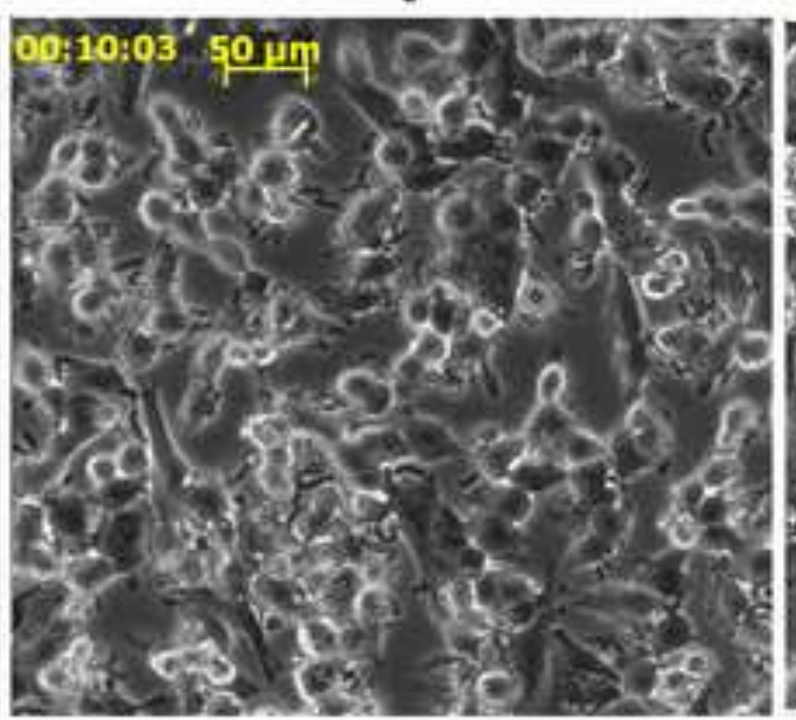

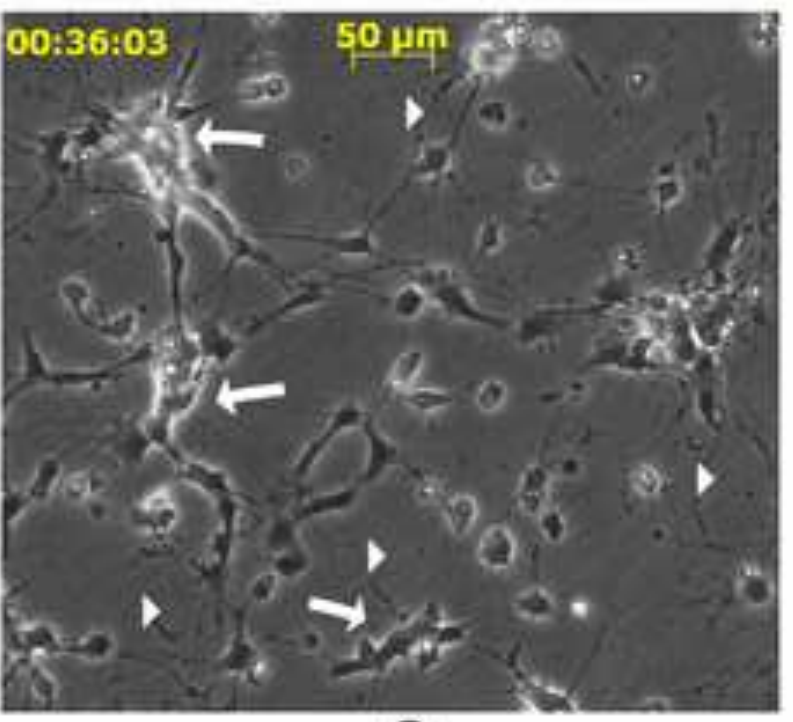

2

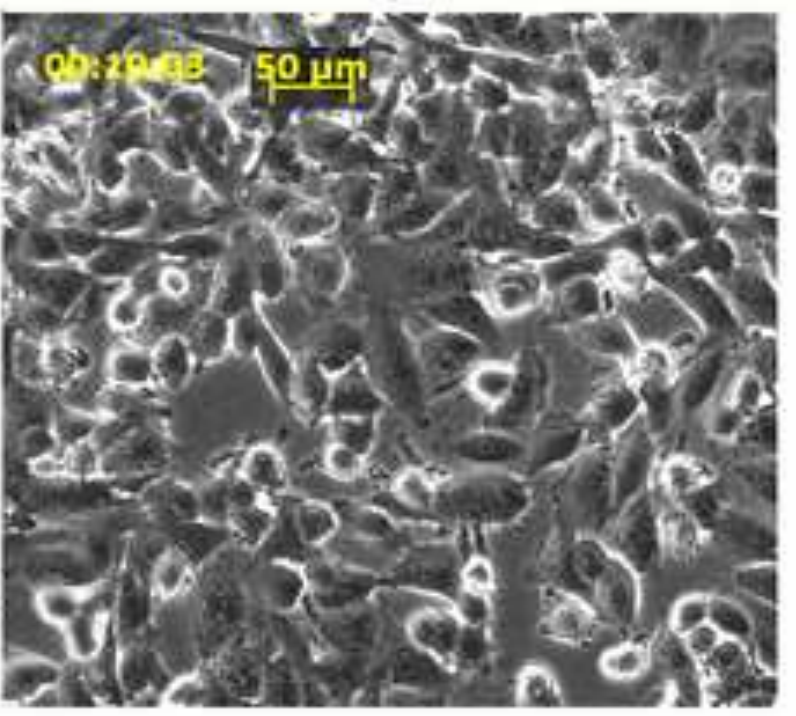



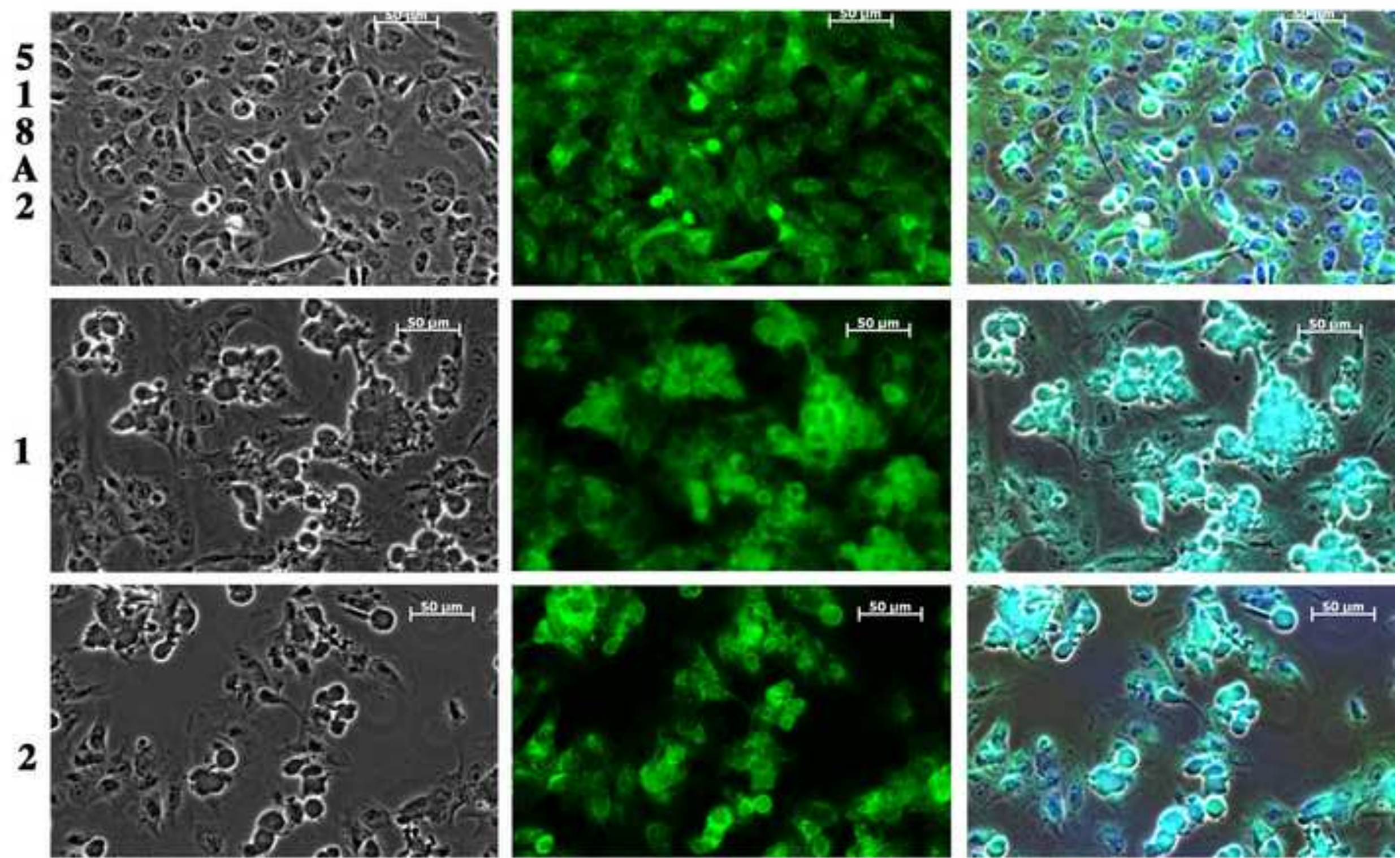

PHASE

ACTIN

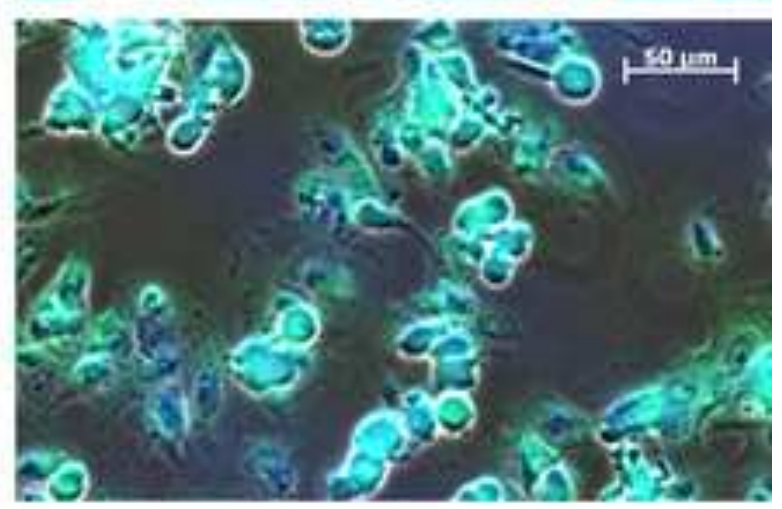

MERGE 


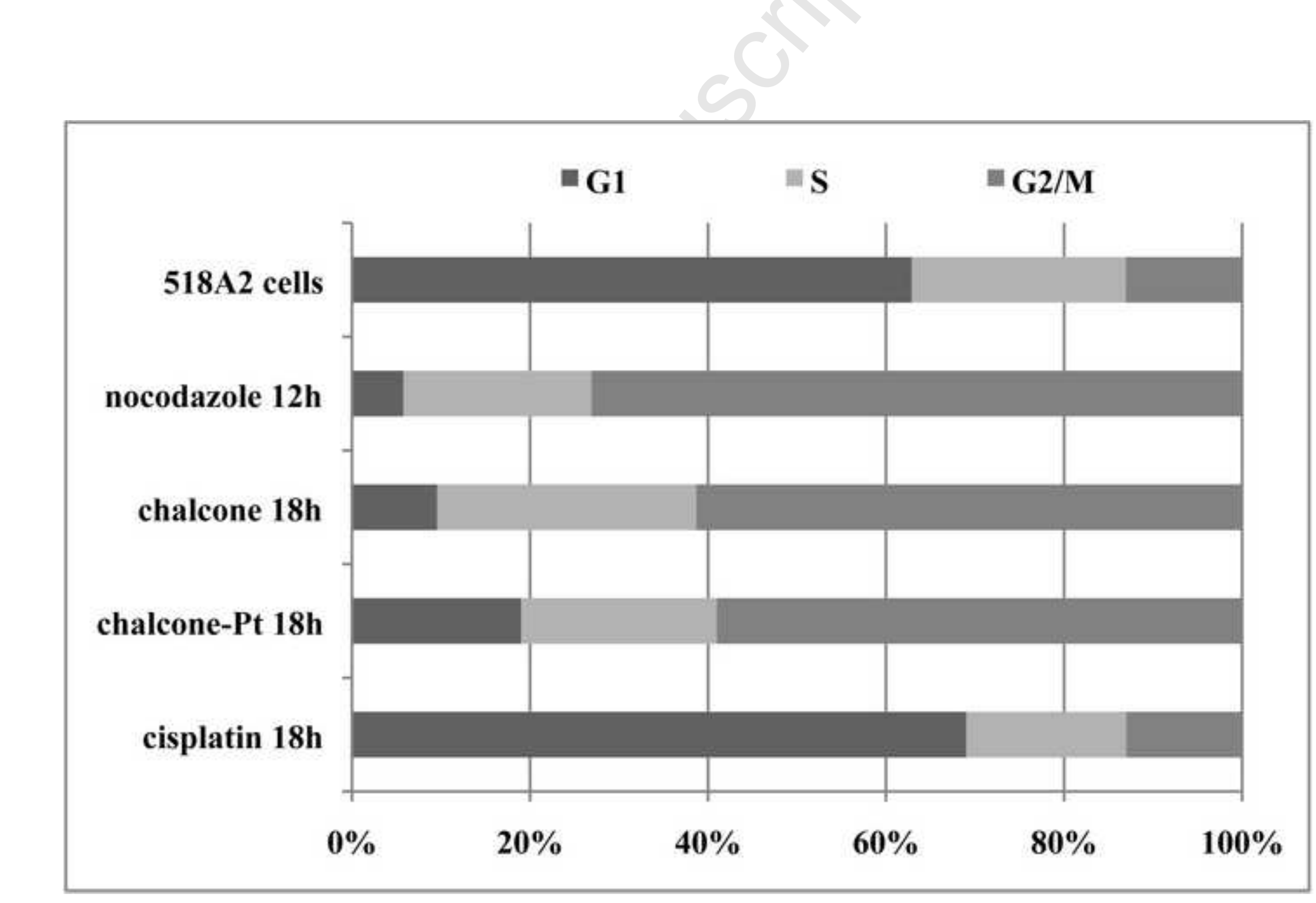
18h

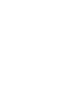

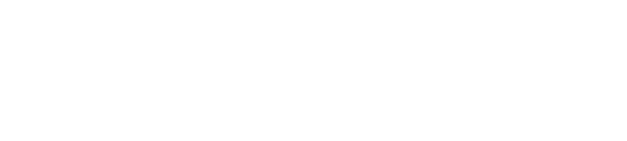

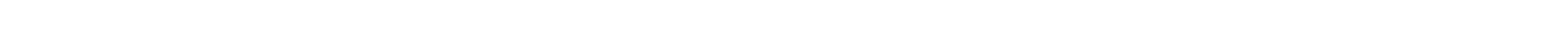



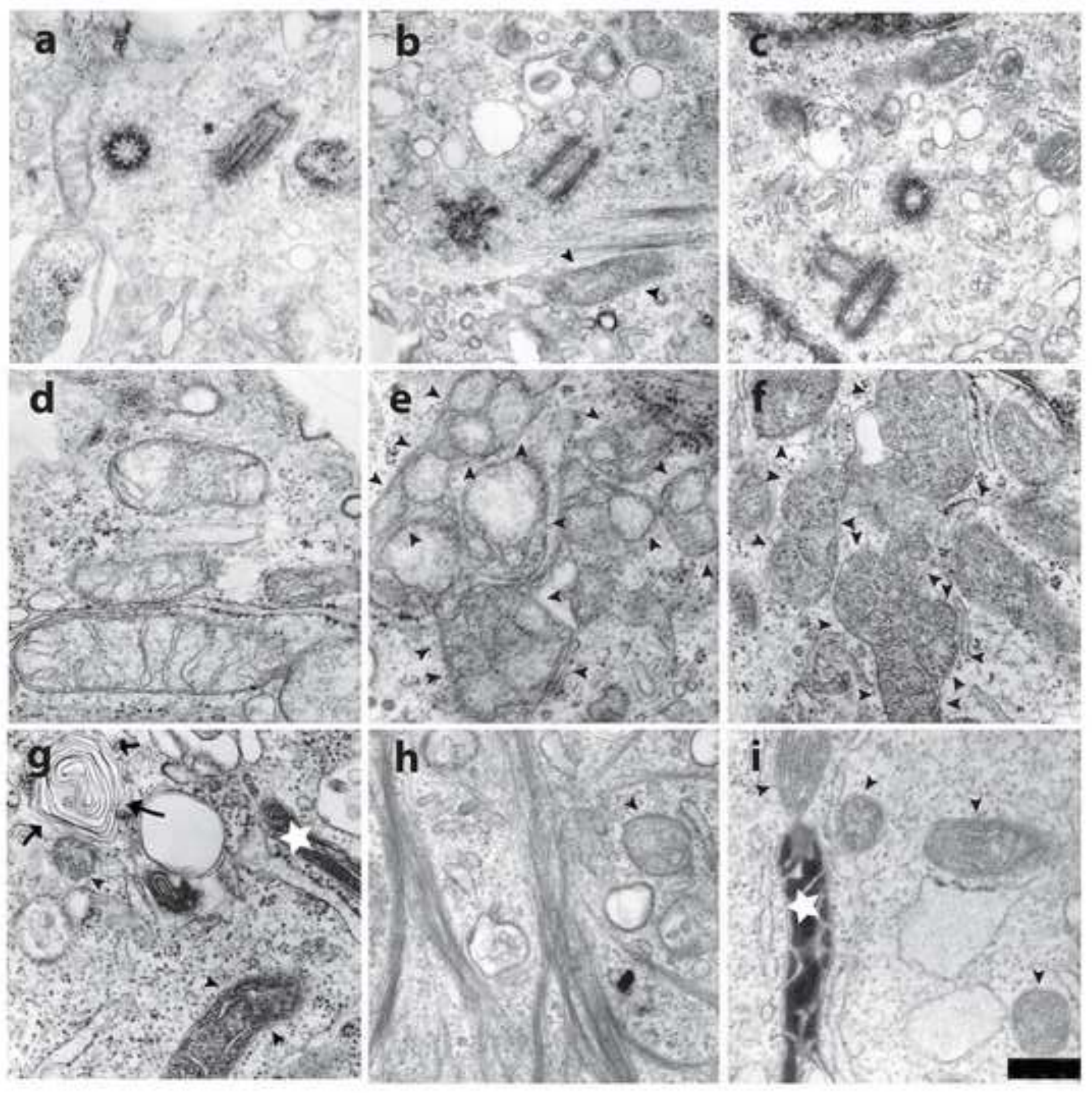

rage 46 oा 48

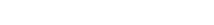

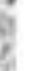

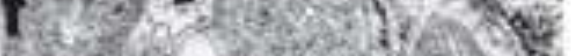

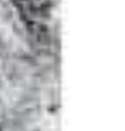
?

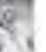
(

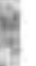
( 

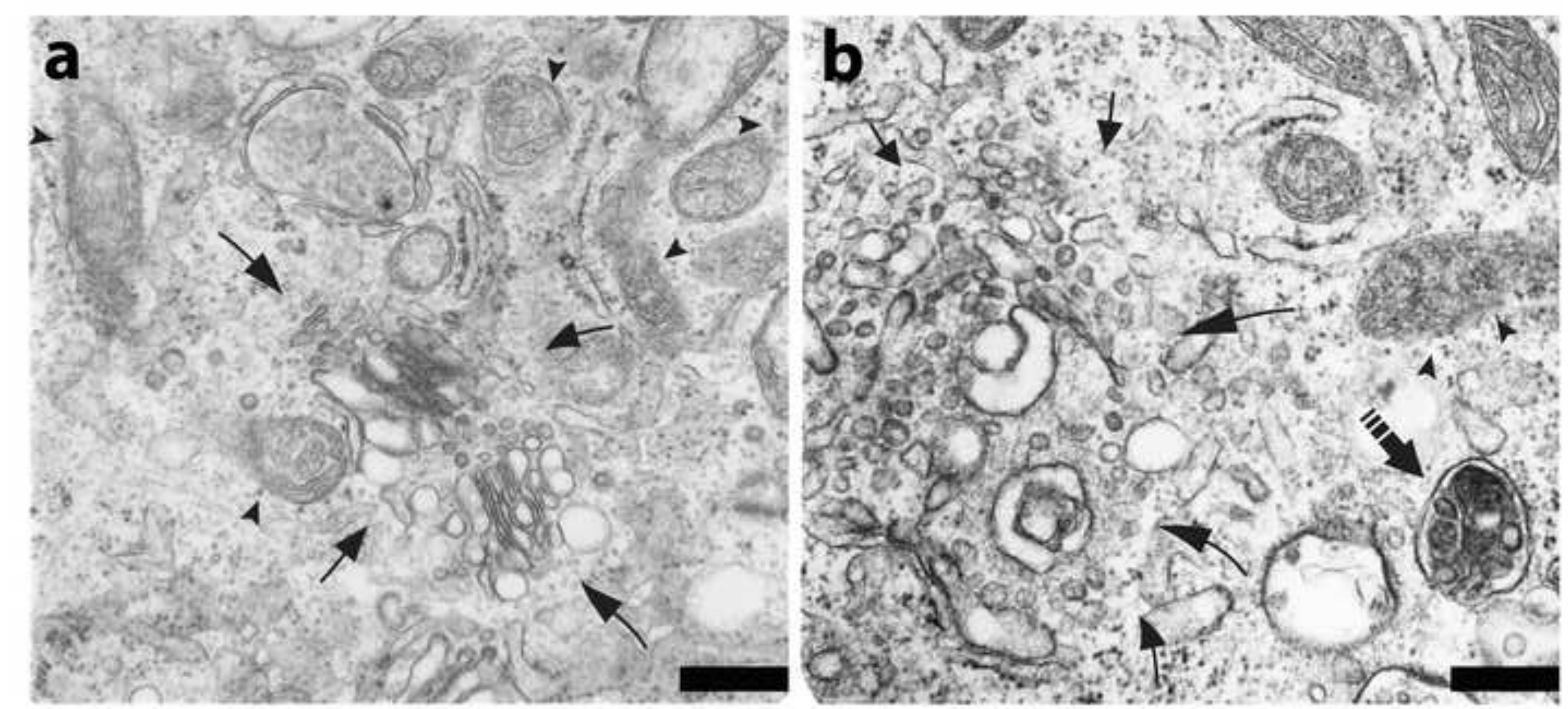


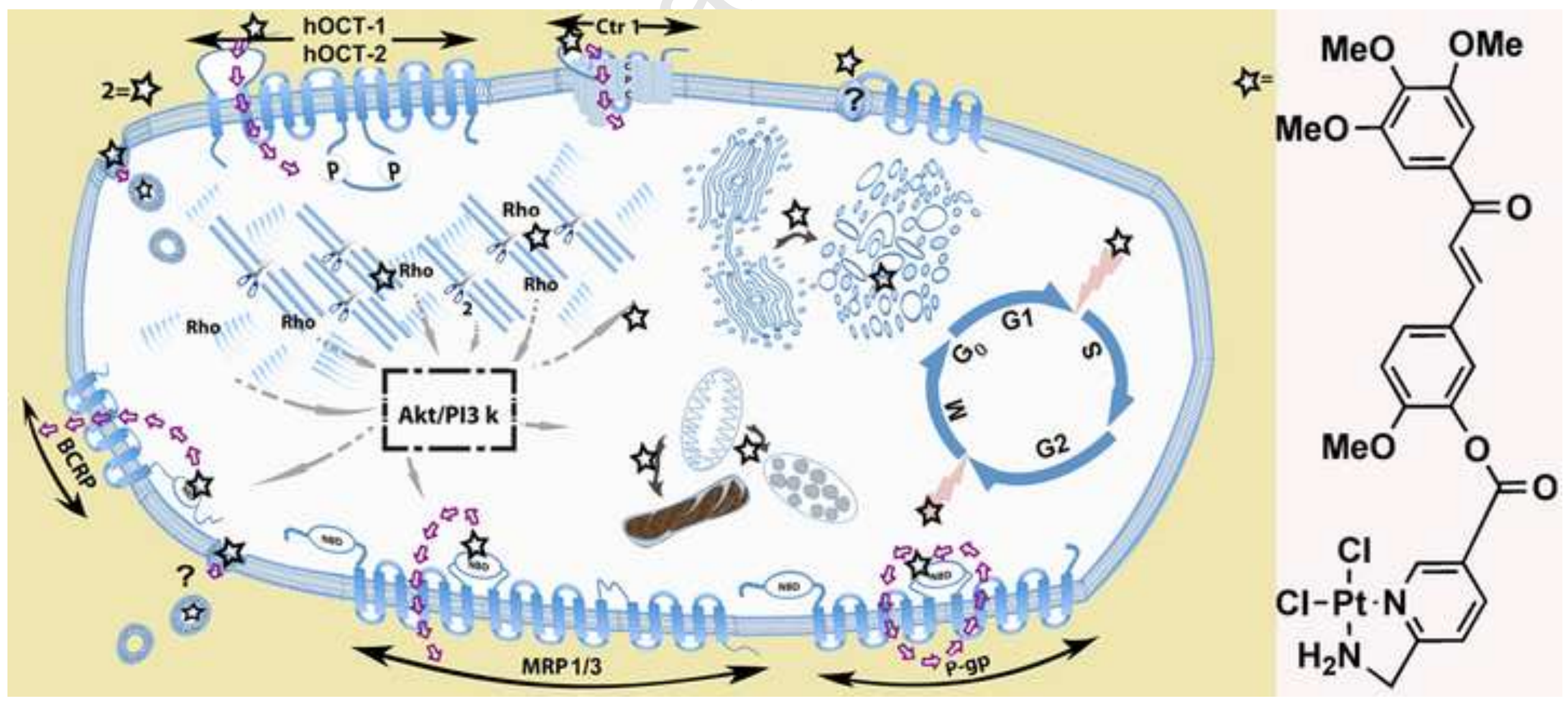

